\title{
Putting the Corporation in its Place
}

TIMOTHY GUINNANE

RON HARRIS

NAOMI R. LAMOREAUX

JEAN-LAURENT ROSENTHAL

This article challenges the idea that the corporation is a globally superior form of business organization and that the Anglo-American common-law is more conducive to economic development than the code-based legal systems characteristic of continental Europe. Although the corporation had important advantages over the main alternative form of organization (partnerships), it also had disadvantages that limited its appeal to small- and medium-sized enterprises (SMEs). As a result, when businesses were provided with an intermediate choice, the private limited liability company (PLLC) that combined the advantages of legal personhood and joint stock with a flexible internal organizational structure, most chose not to organize as corporations. This article tracks the changes that occurred in the menu of business organizational forms in two common-law countries (the United Kingdom and the United States) and two countries governed by legal codes (France and Germany) and presents data showing the rapidity with which firms in each country responded to enabling legislation for PLLCs. We show that the PLLC was introduced first and most easily in a code country (Germany) and last and with the most difficulty in a commonlaw country (the United States). Late introduction was associated with prolonged use of the partnership form, suggesting that the disadvantages of corporations did indeed weigh heavily on SMEs.

(c) The Author 2007. Published by Oxford University Press on behalf of the Business History Conference. All rights reserved. For permissions, please e-mail: journals.permissions@oxfordjournals.org.

doi:10.1093/es/khm067

Advance Access publication July 19, 2007

TIMOTHY GUINNANE is the Philip Golden Bartlett Professor of Economic History in the Department of Economics, and senior research fellow in the MacMillan Center for International and Area Studies, at Yale University. Contact information: Department of Economics, PO Box 208269, Yale University, New Haven CT 06520. E-mail: timothy.guinnane@yale.edu. RON HARRIS is Professor of Law and Legal History, School of Law, Tel Aviv University. Contact information: School of Law, Tel Aviv University, Tel Aviv 69978, Israel. E-mail: harrisr@post.tau.ac.il. 
The idea that the spread of the corporate form of organization was a decisive factor in modern economic growth is pervasive in the literature and must be challenged. ${ }^{1}$ Scholars have argued that only the corporation could provide the lock-in of capital necessary to elicit long-term investments, the limited liability needed to raise capital from the broader public, the entity shielding that could protect the assets of an enterprise from the creditors of its owners, and the

NAOMI R. LAMOREAUX is Professor of Economics and History at the University of California Los Angeles and Research Associate at the National Bureau of Economic Research. Contact information: Department of Economics, 8283 Bunche, 405 Hilgard Avenue, University of California, Los Angeles, CA 90095-1477. E-mail: lamoreaux@econ.ucla.edu.

JEAN-LAURENT ROSENTHAL is Professor of Economics at the California Institute of Technology and Visiting Professor at the Paris School of Economics. Contact information: 228-77 H\&SS, California Institute of Technology, Pasadena, CA 91125. E-mail: jlr@hss.caltech.edu.

We thank Svetlana Alkayeva, Ofira Alon, Juan-Francisco Aveleyra, Christopher Cook, Sarah Cullem, Olga Frishman, Theresa Gutberlet, Adam Hofri, Alena Laptiovna, Maria Polyakova, Itai Rabinowitz, Olga Sedjakina, Sarah Shen, Yvonne Taylor, and Eyal Yaacoby for their excellent research assistance. We are grateful for the financial support of the McMillan International Studies Center and the Millstein Center for Corporate Governance and Performance at Yale University, the International Institute and the Dean of Social Science at UCLA, the UCLA Academic Senate, and the Israel Science Foundation. For comments and suggestions we thank Gary Herrigel, Leslie Hannah, Henry Hansmann, Eric Hilt, Timur Kuran, Jonathan Macey, Roberta Romano, Otto Scherner, Kenneth Sokoloff, Jochen Streb, and two anonymous referees, as well as participants in the 2006 SITE Conference on "Risk, Contracts and Organizations," the XIVth World Economic History Congress in Helsinki, the Paris School of Economics Conference on "Not Just Firms: History, Law, and Economics," and seminars at the Harvard Business School, Haifa University Law School, Max Planck Institute for Research on Collective Goods, Bonn, Paris School of Economics, Rheinisch-Westfälisches Institute für Wirtschaftsforschung, Tel Aviv University Law School, University of British Columbia, University of Mannheim, UCLA's Anderson School and International Institute, and Yale Law School.

1. We are deliberately echoing here Robert Fogel's famous study Railroads and American Economic Growth: Essays in Econometric History (Baltimore, Md., 1964). For a statement of the critical importance of the corporate form for economic development, see Nathan Rosenberg and L. E. Birdzell, Jr., How the West Grew Rich: The Economic Transformation of the Industrial World (New York, 1986). Late passage of legislation enabling general incorporation has often been seen as a cause of economic retardation. See, for example, Charles E. Freedeman, Joint-Stock Enterprise in France, 1807-1867: From Privileged Company to Modern Corporation (Chapel Hill, N.C., 1979), and The Triumph of Corporate Capitalism in France, 1867-1914 (Rochester, N.Y., 1993). 
concentrated management required for effective governance of largescale enterprises. ${ }^{2}$ Although we recognize that the corporate form was important for enterprises such as railroads that had to raise enormous sums of capital on the market, we question whether it was so critical for the vast majority of firms. Indeed, as we will show, when provided with a viable alternative-what we are calling the private limited liability company, or PLLC—most businesses, including most industrial enterprises, chose not to organize as corporations.

As has long been recognized, the corporate form entailed costs as well as benefits. The combination of concentrated management and lock-in of capital that made the form so useful for large-scale enterprises enabled those in control of the firm to behave opportunistically toward minority shareholders and creditors. There is a large literature on corporate governance that addresses this problem. Focusing for the most part on protecting outside investors in corporations that raise funds from the general public, it examines a variety of potential solutions, including government regulation, private oversight by exchanges, monitoring by block holders, and compensation schemes that align managers' incentives with those of owners. ${ }^{3}$

Less attention has been paid to problems of corporate governance in small-and medium-sized enterprises (SMEs), whose shares are neither sold to the public nor traded on the securities markets. Not only do most of the solutions posed in the literature have little relevance to the case of SMEs, but, as we will show, many regulatory efforts

2. Alfred D. Chandler, Jr., The Visible Hand: The Managerial Revolution in American Business (Cambridge, Mass., 1977); Susan E. Woodward, "Limited Liability in the Theory of the Firm," Journal of Institutional and Theoretical Economics 141 (Dec. 1985): 601-11; Robert C. Clark, Corporate Law (Boston, 1986); Margaret M. Blair, "Locking in Capital: What Corporate Law Achieved for Business Organizers in the Nineteenth Century," UCLA Law Review 51 (Dec. 2003): 387-455; Henry Hansmann and Reinier Kraakman, "The Essential Role of Organizational Law,” Yale Law Journal 110 (Dec. 2000): 387-440.

3. The literature goes back, of course, to Adolf A. Berle, Jr., and Gardiner C. Means, The Modern Corporation and Private Property (New York, 1933). See, for examples, Harold Demsetz, "Wealth Distribution and Ownership Rights," Journal of Legal Studies 1 (June 1972): 223-32; Demsetz and Kenneth Lehn, “The Structure of Corporate Ownership: Causes and Consequences," Journal of Political Economy 93 (Dec. 1985): 1155-77; Jeffrey Zweibel, "Block Investment and Partial Benefits of Corporate Control," Review of Economic Studies 62 (April 1995): 161-85; Patrick Bolton and Ernst-Ludwig Von Thadden, "Blocks, Liquidity and Corporate Control," Journal of Finance 53 (Feb. 1998): 1-25; Marco Pagano and Ailsa Roell, "The Choice of Stock Ownership Structure: Agency Costs, Monitoring, and the Decision to Go Public," Quarterly Journal of Economics 113 (Feb. 1998): 187-225; Jean Tirole, “Corporate Governance,'” Econometrica 69 (Jan. 2001): 1-35; Lucian Arye Bebchuk, "Asymmetric Information and the Choice of Corporate Arrangements," Harvard Law School Discussion Paper no. 398 (Dec. 2002). 
to protect outside investors in public corporations actually made the corporate form more onerous for them. Not surprisingly, therefore, when a new form was introduced (the PLLC) that allowed SMEs to obtain many of the advantages of incorporation without bearing all of the costs, it rapidly surpassed the corporation in popularity.

The first mover was Germany, which passed enabling legislation for the Gesellschaft mit beschränkter Haftung (company with limited liability) or $\mathrm{GmbH}$ in 1892. Britain followed in 1907 with a new Companies Act that allowed business people to organize as private limited companies. Other European countries adopted similar legislation in the decades that followed. France, for example, created the Société à Responsabilité Limitée $(S A R L)$ in 1925. The big exception was the United States. Business people in the U.S. really had little choice but to organize as partnerships or corporations until the 1980s and 1990s. Although the corporate form did undergo some modification in the U.S. so that it better met the needs of SMEs, even those changes came rather late-for the most part in the third quarter of the twentieth century.

The purpose of this article is to "put the corporation in its place" and shift the focus of attention to the PLLC-that is, to a form of organization which, we argue, better meets SMEs' contracting needs. In the next section, we describe in greater detail the relative advantages and disadvantages of alternative forms of organization in order to explain the PLLC's appeal. We then explore the history of the form and the extent to which firms took advantage of it in four important countries: Germany, the United Kingdom, France, and the United States. We chose these countries because they were all successful economically and because their legal innovations have been influential around the world. The French and German civil and commercial codes form the basis of business law in many countries in Asia and South America, as well as elsewhere in Europe and in these nations' former colonies. The United Kingdom is widely recognized as the birthplace of the common law. During the era of colonialism its legal regime was transplanted to many parts of the world, where it continues to be important. U.S. corporate law has been promoted as a model that other countries should imitate.

Because we chose to focus on countries that all had strong economies and vibrant SME sectors, our article will not (indeed, cannot) demonstrate that the availability of the PLLC form mattered for economic growth or even for the promotion of SMEs. What we will do, however, is use our evidence to counter a recent trend in the literature that touts the benefits for developing countries of the Anglo-American common law over the German and especially the 
French commercial and civil codes. ${ }^{4}$ We believe that business people have many ways to resolve contracting problems and that in successful economies they devise solutions that are compatible with the legal regimes within which they must operate. We hope that by studying how the menu of organizational choices evolved in these four countries over time, we can help developing countries design business forms that provide incentives to entrepreneurial investment that work well with the institutional structures they inherited.

The Advantages and Disadvantages of Different Organizational Forms

We begin from the perspective of an entrepreneur who wants to establish a business. If she does not have enough wealth to finance the business on her own (or does not want to bear the risk of putting so much of her wealth in one enterprise), she must either borrow or seek an equity investment. Both alternatives involve transaction costs. Because we are interested in the choice of organizational form, we focus our attention on the costs involved in bringing investors into the firm.

In all four of our countries businesses could readily organize as ordinary partnerships in the nineteenth century (table 1). Indeed, in the United Kingdom and the United States all they had to do to be considered at law to be partnerships was to hold themselves out to the world as such. There was no need even to write a partnership agreement. ${ }^{5}$ In France and Germany partnerships also could be informal. If they were organized under the commercial code, however, they had to register their articles of association with the appropriate local authority. One advantage of such registration was that it allowed business people to write contracts modifying the terms of the standard partnership that were enforceable with respect to outside parties. These contracts could be used to concentrate managerial authority in particular partners or require that all members of the firm consent to take on debt. In Britain and the United States

4. See especially Rafael La Porta, Florencio Lopez-de-Silanes, Andrei Shleifer, and Robert W. Vishny, "Legal Determinants of External Finance," Journal of Finance 52 (July 1997): 1131-50; "Law and Finance," Journal of Political Economy 106 (Dec. 1998): 1113-55; and "The Quality of Government," Journal of Law, Economics, and Organization 15 (March 1999): 222-79.

5. Naomi R. Lamoreaux, "Constructing Firms: Partnerships and Alternative Contractual Arrangements in Early-Nineteenth-Century American Business," Business and Economic History 24 (Winter 1995): 43-71. 
Table 1 The Menu of Organizational Choices

\begin{tabular}{|c|c|c|}
\hline Type of Form & Definition of Form & Availability? \\
\hline Ordinary partnership & $\begin{array}{c}\text { Two or more partners, all } \\
\text { unlimitedly liable }\end{array}$ & Yes in all four countries \\
\hline Limited partnership & $\begin{array}{l}\text { One or more general partners } \\
\text { with unlimited liability, and } \\
\text { one or more special } \\
\text { partners who cannot } \\
\text { participate in management } \\
\text { but who have limited } \\
\text { liability }\end{array}$ & $\begin{array}{l}\text { France: yes } \\
\text { Germany: yes } \\
\text { UK: only after } 1907 \\
\text { US: yes, but in an } \\
\quad \text { unattractive form }\end{array}$ \\
\hline $\begin{array}{l}\text { Limited partnership } \\
\text { with tradable } \\
\text { shares }\end{array}$ & $\begin{array}{l}\text { Same as limited partnership, } \\
\text { except special partners' } \\
\text { shares can be bought and } \\
\text { sold on the market }\end{array}$ & $\begin{array}{l}\text { France: yes } \\
\text { Germany: yes } \\
\text { UK: no } \\
\text { US: no }\end{array}$ \\
\hline Corporation & $\begin{array}{l}\text { All members have limited } \\
\text { liability and their shares are } \\
\text { tradable }\end{array}$ & $\begin{array}{l}\text { Required special } \\
\text { permission until: } \\
\text { France: } 1867 \\
\text { Germany: } 1860 \text { s- } 1870 \text {, } \\
\text { varied by state } \\
\text { UK: } 1844 \text { without } \\
\text { limited liability and } \\
\text { 1855-56 with limited } \\
\text { liability } \\
\text { US: mostly middle third } \\
\text { of nineteenth century, } \\
\text { varied by state }\end{array}$ \\
\hline $\begin{array}{l}\text { Private limited } \\
\text { liability } \\
\text { company }\end{array}$ & $\begin{array}{l}\text { All members have limited } \\
\text { liability but their shares are } \\
\text { not tradable }\end{array}$ & $\begin{array}{l}\text { France: } 1925 \\
\text { Germany: } 1892 \\
\text { UK: } 1907 \\
\text { US: } 1870 \text { s-1880s for a } \\
\quad \text { few states, but } \\
\text { unattractive; laws in } \\
\text { 1950s-1970s allowed } \\
\text { close corporations to } \\
\text { mimic; 1980s-1990s }\end{array}$ \\
\hline
\end{tabular}

business people could write such contracts, but they were purely private understandings and hence were not enforceable with respect to outside parties. ${ }^{6}$

The partnership form, of course, had serious disadvantages. Because all partners were unlimitedly liable for the enterprise's debts, business people hesitated to enter into such relationships unless they could extricate themselves when their partners proved untrustworthy or

6. Naomi R. Lamoreaux and Jean-Laurent Rosenthal, "Legal Regime and Contractual Flexibility: A Comparison of Business's Organizational Choices in France and the United States during the Era of Industrialization," American Law and Economics Review 7 (Spring 2005): 28-61. 
took the business in directions that seemed ill-advised. As a result, partnership agreements (even those that specified a term for the enterprise) were effectively at will. ${ }^{7}$ Business people entering into such agreements could not credibly commit to stay in the enterprise, and so partnerships suffered from the possibility that disputes might arise among the firm's various owners that could force what was otherwise a successful enterprise to dissolve. ${ }^{8}$ Presumably, such disputes were somewhat less likely to disrupt businesses in countries like France and Germany where partners could write enforceable contracts that governed the terms of their relationship.

The corporate form protected members of a firm from the risk of untimely dissolution. Shareholders might withdraw from the enterprise by selling their stakes, but they could not force the firm to dissolve or even to refund their investments. This protection came at a cost, however, because corporations subjected their members to other risks as a result of their concentrated management. Although in principle corporate officers and directors served at the pleasure of shareholders, during their terms in office they had considerable leeway to act as they saw fit. Moreover, because replacing them required a substantial ownership stake-half the shares or more-disgruntled shareholders typically found the leadership difficult to depose. As a result, whoever was in control could make decisions with little regard to the interests of other members of the firm and even expropriate some of the minority's earnings. ${ }^{9}$

7. A partner who pulled out of an agreement that had a specified term might face damages, but only if the action was without cause. Courts were reluctant to enforce partnership agreements where there was dissension among members of the firm. See Naomi R. Lamoreaux and Jean-Laurent Rosenthal, "Corporate Governance and the Plight of Minority Shareholders in the United States before the Great Depression,"' in Corruption and Reform: Lessons from America's Economic History, ed. Edward L. Glaeser and Claudia Goldin (Chicago, 2006), 130-33.

8. Although dissolution does not necessarily entail liquidation, there is always the possibility that illiquid firm-specific assets will have to be sold at a loss to pay off creditors or to buy out members of the firm. Dissolution can also be forced by the creditors of one of the members of the firm if that member is otherwise unable to pay off his or her debts. See Hansmann and Kraakman, "The Essential Role of Organizational Law"; and Henry Hansmann, Reinier Kraakman, and Richard Squire, "Law and the Rise of the Firm," Harvard Law Review 119 (March 2006): 1333-1403. See also Joshua Getzler and Mike Macnair, "The Firm as an Entity before the Companies Act," in Adventures in the Law: Proceedings of the 16th British Legal History Conference, eds. Paul Brand, Kevin Costello, and W. N. Osborough (Dublin, 2003), 267-88.

9. Lamoreaux and Rosenthal "Corporate Governance and the Plight of Minority Shareholders"; and "Contractual Tradeoffs and SME's Choice of Organizational Form: A View from U.S. and French History," NBER Working Paper no. W12455 (Aug. 2006). 
The extent to which minority investors in corporations could protect their interests varied from one country to the next, depending on the flexibility built into the general incorporation statutes. In Britain, France, and Germany incorporators could write governance rules that increased the voting power of minority shareholders. ${ }^{10}$ In the United States, by contrast, over time more and more states required directors to be chosen by simple majorities in annual elections where each stockholder exercised one vote per share. As late as the 1950s, moreover, there was a high probability that shareholders' agreements that required supermajority votes for corporate decisions would be overturned by U.S. courts. ${ }^{11}$

Despite the comparative inflexibility of the corporate form in the United States, relatively more firms organized as corporations there than anywhere else. On the eve of World War I, there were about 250,000 corporations in the United States (about 2.5 corporations for every 1,000 people), compared to roughly 5,100 in Germany (less than 0.1 per 1,000), 13,000 in France (more than 0.3 per 1,000), and 63,000 in the United Kingdom (more than 1.3 per 1,000). ${ }^{12}$ As we

10. L. C. B. Gower, "Some Contrasts Between British and American Corporation Law," Harvard Law Review 69 (June 1956), 1376-77; Colleen A. Dunlavy, "From Citizens to Plutocrats: Nineteenth-century Shareholder Voting Rights and Theories," in Constructing Corporate America: History, Politics, Culture, ed. Kenneth Lipartito and David B. Sicilia (New York, 2004), 84.

11. Gower, "Some Contrasts Between British and American Corporation Law," 1376-77; and Dunlavy, "From Citizens to Plutocrats," 82-84. For example, Pennsylvania law required directors to be chosen "by the vote of its stockholders holding a majority in interest of all of its stock" (Ardemus Stewart, comp., A Digest of the Statute Law of the State of Pennsylvania from the Year 1700 to 1903 [Philadelphia, 1905], 797). Ohio's general incorporation law included a similar rule, declaring "directors shall not be elected in any other manner" (William Herbert Page, ed., New Annotated Ohio General Code [Cincinnati, 1926], 8636). Both states did, however, allow some flexibility by permitting the adoption of cumulative voting rules that gave minority shareholders somewhat more power. New Jersey's statute allowed incorporators to write their own governance rules (see Compiled Statutes of New Jersey [Newark, 1911], 1606), but the courts nonetheless interpreted the statutory norms fairly narrowly and struck down some alternative governance schemes. See Edward R. Schwartz, "The Limited Partnership Association-An Alternative to the Corporation for the Small Business with 'Control' Problems?', Rutgers Law Review 20 (Fall 1965), 29; and George D. Hornstein, "Stockholders' Agreements in the Closely Held Corporation," Yale Law Journal 59 (May 1950), 1042, 1045. Key cases that enforced standard governance rules include Jackson v. Hooper, 76 N.J. Eq. 592 (1910); In the Matter of Boulevard Theatre and Realty Company, 186 N.Y.S. (1921); and Benintendi v. Kenton Hotel, 294 NY 112 (1945).

12. The vast majority of the corporations in Britain were actually PLLCs, as we will show below. Only about 1,000 were what were called public corporations. Freedeman, The Triumph of Corporate Capitalism, 21; Susan Carter, et al., Historical Statistics of the United States: Millennial Edition (New York, 2006), vol. 3, tables Ch 1-18. 
will show, to some extent these differences resulted from regulatory provisions that affected the relative attractiveness of the form. But they also resulted from differences across countries in the availability of alternative organizational forms that allowed firms to reduce the risk of untimely dissolution, the cost of minority oppression, or both. ${ }^{13}$ On the European continent, for example, firms could organize as limited partnerships in which one or more partners had limited liability but could not participate in the firm's management (table 1). These kinds of enterprises had somewhat more protection against untimely dissolution than did ordinary partnerships because the limited partners could not pull their investments out of the firm before the expiration of the agreed upon term. The disadvantage was that the limited partners had no say in the way their investments were being used and hence could be exploited by the managing partners. Because the term of the enterprise was finite, however, limited partners were somewhat less vulnerable than minority shareholders in corporations.

In Britain there was no enabling statute for limited partnerships until 1907 - long after the passage of general incorporation laws - and the courts effectively blocked all efforts to create limited or sleeping partnerships contractually. ${ }^{14}$ The situation was similar in the United States. Although most states passed laws during the 1820s and 1830s that permitted the formation of limited partnerships, the courts construed these statutes narrowly, exposing the special partners to unlimited liability in circumstances beyond their control. As a result, the limited partnership never provided a serious alternative to the ordinary partnership. ${ }^{15}$

The more important intermediate form was the PLLC, which as we have already noted became available to German businesses in

13. Today, of course, tax rules have significant effects on businesses' decisions whether to organize as corporations. Before the mid-twentieth century, however, tax rates were low. So even where there were differences in treatment across organizational forms, the effects were small. For the purposes of this paper we largely set aside tax issues, though we will return to the subject in subsequent work.

14. Ron Harris, Industrializing English Law: Entrepreneurship and Business Organization, 1720-1844 (Cambridge, U.K., 2000), 20.

15. Stanley E. Howard, "The Limited Partnership in New Jersey," Journal of Business of the University of Chicago 7 (Oct. 1934): 296-317; William Draper Lewis, "The Uniform Limited Partnership Act," University of Pennsylvania Law Review 65 (June 1917), 716-18. In Britain and the United States firms could also organize as joint stock companies and trusts. The former were legally partnerships and had many of the disadvantages of the form. In the latter investors had so completely to relinquish managerial authority to the trustees that they were more vulnerable to oppression than in any other form. Edward H. Warren, Corporate Advantages Without Incorporation (New York, 1929), 302-404. 
1892, British in 1907, French in 1925, and in the United States only much later. Founders of PLLCs generally had considerable freedom to determine their governance rules and organizational structures. By requiring super majorities for important decisions, they could make it more difficult for the majority to oppress the minority, though of course super-majority voting rules could lead to stalemate when stakeholders held different beliefs about the optimal course of action for the firm. PLLCs could also include provisions in their articles of association that made it more or less easy for members to exit, but again there was a trade-off. Although ease of exit might be a useful way of disciplining management, locking in capital could be an important way of encouraging members to make noncontractible investments. For some types of businesses the costs of minority oppression outweighed the risks of untimely dissolution, but for other types of businesses the situation was just the opposite. The great advantage of the PLLC form is that it enabled business people to choose more or less risk of oppression versus untimely dissolution as met the needs of their enterprise.

\section{The Advent of the PLLC}

Today all of the countries we are studying offer firms an extensive menu of organizational choices. In the past, however, the extent and flexibility of the alternatives available to business enterprises varied a great deal from one polity to another. In the next several sections we track the changes that occurred in the menu of organizational forms in each of our four countries since the mid-nineteenth century. We also present data showing how firms in these countries responded to changes in the menu of choices.

We devote particular attention to statutes that permitted firms to adopt the PLLC form. Intriguingly, despite the advantages we claim for the form, in no country did business people perceive in advance the organizational benefits of the PLLC and lobby for the passage of enabling legislation. Rather, the impetus for the legislation seems to have had exogenous causes. In Germany and Britain the spur was regulatory initiatives that raised the cost of adopting the corporate form; in France, the return of Alsace and Lorraine after World War I; in the United States, changes in the burden and incidence of the federal income tax after World War II. Regardless of the cause, wherever and whenever the PLLC became available, it (sometimes gradually, sometimes much more rapidly) became the preferred form for SMEs. 


\section{Organizational Choice in Germany}

Until the last third of the nineteenth century businesses in the various German states could freely choose among three basic organizational forms: the commercial partnership (Offene Handelsgesellschaft or OHG), the simple limited partnership (Kommanditgesellschaft or KG), and the limited partnership with tradable shares (Kommanditgesellschaft auf Aktien or KGaA). ${ }^{16}$ To organize as a corporation a business had to secure explicit permission from the government. Some states were relatively liberal in granting corporate charters, often seeking tax revenue or other favors from corporations that would do most of their business elsewhere in the region. Others learned the hard way that a restrictive policy would not prevent corporations from being created but rather would only lead to their being chartered in another German state. ${ }^{17}$ The passage of general incorporation laws created similar, though even more intense pressures. The $A D H G$ of 1861 maintained the concession system, but $\S 249$ permitted individual German states to adopt general incorporation. The North German Confederation (led by Prussia) took advantage of this provision in 1870, and it was carried over into Reich law in 1871. According to Nobert Horn, "numerous" states, including most of the Hanseatic cities, had adopted general incorporation before $1870 .^{18}$

The passage of general incorporation laws spurred an increase in the number of new corporations. The upsurge was particularly large during the "Gründerboom” of 1871-1873, when the rapid payment of the indemnity imposed after the Franco-Prussian war produced a short-lived stock-market bubble. In 1871 businesses registered 104 corporations in Berlin alone. ${ }^{19}$ Many of the new enterprises reflected over-heated expectations or outright fraud, and the collapse of the bubble brought a number of them down. Of the 1,005 corporations

16. After 1861 most German states agreed to adopt a common code of business law (the Allgemeine Deutsche Handelsgesetzbuch or ADHG), so most aspects of these forms were the same everywhere. Prior to 1900, the several states and regions of Germany had distinct civil law systems. For the purposes of this paper, these distinctions are relatively unimportant.

17. Rondo Cameron, "The Founding of the Bank of Darmstadt," Explorations in Entrepreneurial History 8 (Feb. 1956): 112-30.

18. Nobert Horn, "Aktienrechtliche Unternehmensorganisation in der Hochindustrialisierung (1860-1920)," in Recht und Entwicklung der Grossunternehmen im 19. und frühen 20. Jahrhundert, eds. Norbert Horn and Jürgen Kocka (Götting, 1979), 128, and note 22.

19. Carsten Burhop, Die Kreditbanken in der Gründerzeit (Stuttgart, 2004), 25. 
formed during the period 1867-1873, 123 were in liquidation by September 1874, and another 37 were in bankruptcy. ${ }^{20}$

Fallout from the bubble's collapse led to the passage in 1884 of a set of legislative reforms intended to enhance the power of shareholders and prevent abuses in the formation of new enterprises. One set of reforms strengthened the role of the supervisory board (Aufsichtsrat) and required more detailed reporting of financial conditions. Other changes raised the minimum size of a share ten-fold, to 1,000 Marks, and forbade new corporations from operating until all their shares had been subscribed. Firms that converted to the corporate form could not list their shares on the stock market until one year after the reorganization. ${ }^{21}$

These changes undoubtedly made the corporate form less attractive to entrepreneurs. ${ }^{22}$ Although it is not at all remarkable that the number of new corporations declined dramatically after 1873 in response to the collapse of the market and the bad reputation the corporation had acquired, it is significant that the number never again exceeded 400 firms per year in the nineteenth century. Some enterprises that one would expect a priori to be organized as corporations chose another form. Jürgen Kocka and Hannes Siegrist report that fifteen of the 100 largest industrial enterprises in Germany in 1887 were Personengesellschaften (either partnerships or single-owner firms). In 1907, the number was still seven out of $100 .{ }^{23}$ Even today, some of

20. Eduard Wagon, Die finanzielle Entwicklung deutscher Aktiengesellschaften von 1870-1900 und die Gesellschaften mit beschränkter Haftung im Jahre 1900 (Halle, 1903), 3.

21. Gesetz, betreffend die Kommanditgesellschaften auf Aktien und die Aktiengesellschaften, vom 18. Juli 1884/Mit Erlauterung von Paul Kayser (Berlin, 1884). There was no external auditing of corporations until 1931; the supervision committee was supposed to act as a sort of internal auditor.

22. As Timothy W. Guinnane has pointed out, the changes strengthened the role of the Great Banks in company formation with the result that profits from such activities were increasingly captured by bankers. See "Delegated Monitors, Large and Small: Germany's Banking System, 1800-1914," Journal of Economic Literature 40 (March 2002): 104-05. Caroline Fohlin also stresses the effect of the 1884 changes, but her focus is on the implications for banks. See "Regulation, Taxation, and the Development of the German Universal Banking System, 1884-1913,'” European Review of Economic History 6 (Aug. 2002): 221-54.

23. Jürgen Kocka and Hannes Siegrist, "Die hundert größten deutschen Industrieunternehmen im späten 19. und frühen 20. Jahrhundert," in Recht und Entwicklung der Grossunternehmen im 19. und frühen 20. Jahrhundert: Wirtschafts-, sozial- und rechtshistorische Untersuchungen zur Industrialisierung in Deutschland, Frankreich, England und den USA, eds. Norbert Horn and Jürgen Kocka (Göttingen, 1979), 80-81, Tables 1 and 2. 
the largest German firms are organized as partnerships of one type or another. Merck's German parent company is a KGaA, for example. ${ }^{24}$

By the late 1880s many observers in Germany thought that the 1884 reforms had gone too far. Because the new regulations had made the formation of medium-scale corporations so unattractive, they had created a barrier to entry that was contributing to the growing concentration of economic power in Germany. Demands for change included calls for revising the AG as well as for the creation of a new form of enterprise. Formal consideration of the latter possibility began in 1888 when the Prussian Minister of Commerce asked the Handelskammer (German Commercial Associations) to discuss the desirability of new corporate forms at its next meeting. After consultation with this and other interested groups, the Ministry of Justice circulated a draft version of the law. The Reichstag passed enabling legislation for the Gesellschaft mit beschränkter Haftung (company with limited liability, later usually abbreviated $\mathrm{GmbH}$ ) in 1892. The form was later incorporated, with minor modifications, into the first post-unification commercial code (the Handelsgesetzbuch or HBG) of $1898 .{ }^{25}$ Although some observers, such as Hans Crüger, saw the $\mathrm{GmbH}$ as a way for smaller enterprises to survive and prosper, the new form did not meet with anything like universal approval. ${ }^{26}$ Legal thinking at the time made a sharp distinction between an association of people (Personengesellschaft) such as a partnership or limited partnership, on the one hand, and an association of capital (Kapitalgesellschaft) such as an AG on the other. By straddling this distinction the $\mathrm{GmbH}$ offended the sensibilities of the legal profession. Nonetheless, for all the complaints about the GmbH over the years, the form as used today remains virtually unchanged from 1892. ${ }^{27}$

A $\mathrm{GmbH}$ was created when legally valid articles of incorporation (Gesellschaftsvertrag) were entered in the relevant commercial register. The firm's legal name (Firma) had to include the phrase "with limited liability," but beyond that the law placed few constraints on

24. The general partner is an OHG owned by the Merck family. Other large partnerships in Germany today include Henkel KGaA and the Oppenheim banking firm.

25. Werner Schubert, "Die Gesellschaft mit beschränkter Haftung. Eine neue juristische Person," Quaderni fiorentini per la storia del pensiero guiridico moderno 11/12 (1982): 589-629.

26. Hans Crüger, Die Gesellschaft mit beschränkter Haftung (Berlin, 1912). Crüger was the leader of the urban branch of the cooperative movement.

27. Karsten Schmidt, Gesellschaftsrecht (4 $4^{\text {th }}$ ed., Berlin, 2002). 
the articles of incorporation. ${ }^{28} \mathrm{~A} \mathrm{GmbH}$ had to have an issued capital (Stammkapital) of at least 20,000 Marks. ${ }^{29}$ The law implied that there had to be at least two shareholders (Gesellschafter) to register the firm, but that a legally valid $\mathrm{GmbH}$ could consist of a single shareholder once the enterprise was registered. ${ }^{30}$ The total Stammkapital could be divided into (not necessarily equal) shares, but no share could be less than 500 Marks. ${ }^{31}$ At least 25 percent of the capital had to be paid in before the $\mathrm{GmbH}$ could operate. An important difference between a $\mathrm{GmbH}$ and an $\mathrm{AG}$ was that transfer of a share in a $\mathrm{GmbH}$ required a notarial contract. As a result, the cost of transfers was higher, and shares could not trade on stock markets.

Most important organizational matters were left to the firm's owners, although the law did stipulate some default rules, allowing the articles to be brief and simple. A GmbH could be formed for a limited period of time or without a specified term; in either case investors were protected against the threat of untimely dissolution by a default rule that required the approval of three-quarters by value of the shares to wind up the firm. Under the default rules, however, this protection came at the cost of an increased risk of minority oppression similar to that of a corporation. Each 100 Marks of invested capital was to be treated as a single vote, and simple majorities carried in elections for managers and for most corporate decisions, making it

28. A GmbH could be organized for any legal purpose, including not-forprofit activities, though in a few specialized activities (such as banking) firms faced special reporting requirements that we will not detail here. Any enterprise organized as a $\mathrm{GmbH}$ was automatically a commercial firm (Handelsgesellschaft) in the sense of the HGB, regardless of what it actually did. Although the 1892 law never actually defined what a $\mathrm{GmbH}$ was, it clearly stated that the $\mathrm{GmbH}$ is a legal person with the right to act in its own name.

29. In $1892,20,000$ Marks equaled $£ 1,000$, or about $\$ 4,860$. This was a large sum; per-capita GDP in Germany in 1892 was 470 Marks. Walther G. Hoffmann, Das Wachstum der deutschen Wirtschaft seit der Mitte des 19. Jahrhunderts (Berlin, 1965), 248, Table 1.

30. As early as 1900 commentators were noticing the emergence of "one-man GmbHs" formed by arranging in advance for one shareholder to buy out the others. Edgar Guilini reported that 115 of the $1125 \mathrm{GmbHs}$ operating in Berlin in 1905 had only one Gesellschafter. See Die Gesellschaft mit beschränkter Haftung nach Vereinigung aller Geschäftsanteile in einer Hand (Heidelberg, 1919), 4.

31. The GmbH's shares are called Anteilen rather than Aktien, the term used for shares in a corporation. The terminology reflects the intention that ownership in a $\mathrm{GmbH}$ would not be traded in active markets as with the AG. Some writers refer in English to the GmbH's owners as "quota holders" rather than "shareholders" to capture the German distinction. See, for example, Henry P. De Vries and Friedrich K. Jünger, "Limited Liability Contract: The GmbH," Columbia Law Review 64 (May 1964): 866-86. We think "quota-holder" is too awkward to justify any clarity it might bring. 
possible for owners representing 51 percent of the capital to impose their will on those owning 49 percent. But these were only default provisions. Organizers could agree to other rules on these matters, trading off more risk of untimely dissolution against less danger of minority oppression, if they so chose.

The $\mathrm{GmbH}$ law required each firm to have one or more managers (Gesellschaftsführer), who might but did not have to be shareholders. Because the managers represented the firm legally, their names had to be entered in the commercial registry. A GmbH could also have a supervisory committee, but unlike an $\mathrm{AG}$ or $\mathrm{KGaA}$, it did not have to have one. By law stockholders had an unequivocal right to dismiss managers whenever they wanted. This provision prevented the creation of a manager-as-dictator. ${ }^{32}$

Minority shareholders obtained additional protection from their ability to exit the firm. Shares had to be alienable and heritable. Although the articles of association could limit transferability, for example by requiring that the other owners had to approve sales to outsiders, these provisions could not harm any shareholder's ability to exit. Conversely, GmbHs had the right to expel owners by buying back their shares. This provision was related to other sections of the law that permitted the firm to require shareholders to perform specific functions. Thus the articles of association might specify that certain shareholders must act as managers, inventors, or even creditors to the firm. The articles could also require them to make supplementary contributions to capital. Failure to adhere to such requirements was adequate reason to seize an owner's shares.

In Germany all firms that organized under the commercial code were required to draft formal written agreements and register the main details of these agreements with a local authority. The filings were published each business day in the Anzeiger, enabling us to track trends over time in the use of the different organizational forms. ${ }^{33}$

32. Max Hachenburg stresses that any provision of the firm's articles of association that would limit the firm's ability to fire its manager is invalid. Hachenburg's was the authoritative commentary on the $\mathrm{GmbH}$ law into the 1920s. Hachenburg uses the word Willkür, which underlines the firm's ability to act arbitrarily in this regard. See Hachenburg, Staub's Kommentar zum Gesetz, betreffend die Gesellschaften mit beschränkter Haftung (4th ed., Berlin, 1913), $441-42$.

33. The Deutscher Reichsanzeiger und preussischer Staatsanzeiger (before 1871, the Königlich preussischer Staats-Anzeiger) was a publication used for official announcements, including entries in the commercial registries maintained across Germany. Firms could also use it to satisfy publicity requirements, such as the requirement that all corporations publish annual financial statements. 


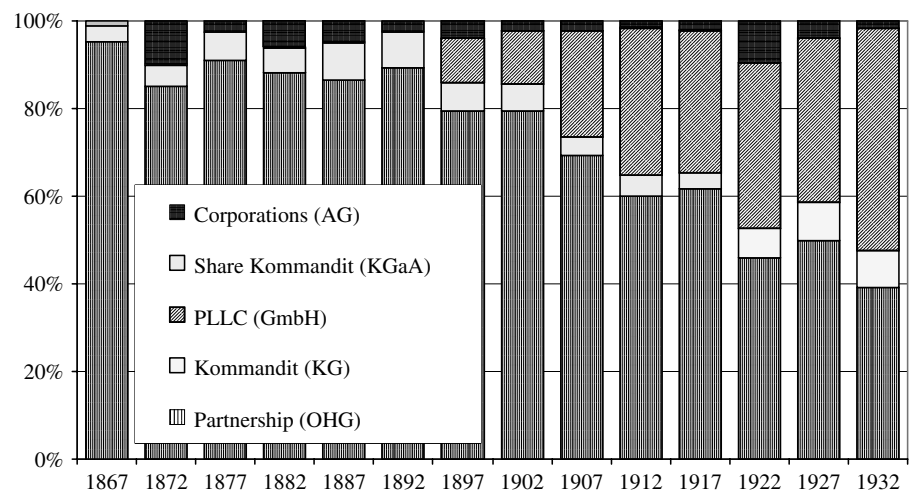

Source: Data were compiled from the Königlich preussischer Staats-Anzeiger (until 1871) and the Deutscher Reichsanzeiger und preussischer Staatsanzeiger (after 1871). We counted every new firm announced by a commercial registry in Januaries of the years reported. Note that the source pertains to Prussia only.

Figure 1 Distribution of New Firms Among Multi-Owner Organizational Forms: Prussia, 1867-1932.

Figure 1 reports estimates of the choices made by new firms that registered in Prussia at five-year intervals, starting with 1867. As the figure shows, the GmbH's popularity grew slowly during its first decade of existence, but by 1912 about one-third of new firms took the form, and by $1932 \mathrm{GmbHs}$ accounted for about half of all new registrations.

As might be expected, the advent of the $\mathrm{GmbH}$ had little effect on the proportion of new firms organized as AGs. Both before and after the 1892 legislation corporations were extremely rare; only about twenty were formed in Prussia each January between 1872 and 1912, despite considerable economic growth over the period. Because of the high cost of incorporation, only those businesses for which the form offered significant advantages were likely to take out charters. ${ }^{34}$ Analysis of employment patterns from the 1907 census of firms and occupations bears out this argument. Corporations accounted for only 0.3 percent of all firms (7 percent of multiowner firms), but they employed more than 12 percent of the workforce. Moreover, their average size (180 workers per firm) dwarfed that of the $\mathrm{GmbH}$ (49 workers per firm). ${ }^{35}$

The GmbH also had little effect on the Kommandit, which remained a reasonably constant 8 percent share of all registrations. Instead, the

34. Not surprisingly, few AGs converted to GmbHs. Once a firm had born the costs of organizing as a corporation, it probably did not make much sense to give up the form.

35. Richard Passow, "Der Anteil der verschiedenen privaten Unternehmungsformen und der öffentichen Betrieben am deutschen Wirtschaftsleben,'” Jahrbücher für Nationalökonomie und Statistik N.F. 96, no. 4 (1911): 506-25. 
GmbH's primary impact was to provide limited liability and a sharecapital structure to firms that otherwise would have decided to forego these advantages and organize as partnerships, either because the costs associated with forming an AG were too high or because of the greater risk of minority oppression that organizing as an AG or a KG entailed. The share of ordinary partnerships fell steadily after the $\mathrm{GmbH}$ was enacted, dropping in Prussia from nearly 90 percent in 1892 to less than 40 percent four decades later, and it is reasonable to assume that the effect on partnerships would have been even greater if the minimum capital requirement for $\mathrm{GmbHs}$ had not been set so high. In 1913, about one-third of all Prussian GmbHs had precisely the threshold 20,000 Marks of Stammkapital. ${ }^{36}$

\section{Organizational Choice in Britain}

In Britain there was no law permitting limited partnerships until 1907, and the courts effectively blocked all efforts to create silent or sleeping partnerships contractually. British businesses, therefore, had only two organizational choices in the nineteenth century: the partnership and the corporation. As was the case in Germany and elsewhere, incorporation initially required government approval, and lobbying by opponents (particularly competitors who sought to prevent rivals from obtaining special privileges) made corporate charters a rare and expensive commodity until Parliament enacted legislation providing for general incorporation in 1844. The Companies Act of that year permitted joint-stock enterprises to incorporate freely without limited liability. General incorporation with limited liability was made available in 1855-1856. ${ }^{37}$

After the passage of these laws, forming a corporation in Britain was a relatively simple and inexpensive process, and the number of firms that chose this option steadily increased. Annual registration was 580 in 1870, 1,269 in 1880, 2,692 in 1890, and 4,849 in $1900 .{ }^{38}$ Many of the

36. The smallest size category of GmbHs accounted over time for an increasing proportion of firms taking the form. In 1904, 40 percent of all $\mathrm{GmbHs}$ operating in Prussia had a Stammkapital of 20,00 to 50,000 Marks. By 1913, the percentage was 58. Statistisches Jahrbuch für den Preussischen Staat (Berlin, 1915), vol. 12, Table VII. B1, p. 221, and Table VII. B2, p. 222.

37. See Harris, Industrializing English Law, 288. The Companies Act of 1844, which introduced general incorporation, declared unregistered joint-stock companies illegal and prohibited the formation of partnerships with more than twenty five members.

38. U.K. Board of Trade, General Annual Report (London, 1923). 
charters, of course, were taken out by large firms. Surveys of important industries, such as cotton spinning, iron and steel, and shipping, for years ranging from 1884 to 1891 suggest that 25 to 50 percent of all large enterprises took the corporate form. For the years 1900 to 1914 the percentage in comparable surveys rose to 80 to 90 percent. ${ }^{39}$ In 1904-1905, 35 percent of all tax paying firms were companies; by 1913-1914 the percentage was $53 .{ }^{40}$ As these latter figures suggest, increasing numbers of SMEs were also organizing as corporations. Firms found ways to get around the legal requirement that they have a minimum of seven shareholders by recruiting dummy members to whom they would give a small number of shares. Even singleowner enterprises learned that they could organize as corporations by allotting one share each to six nominal members of the firm, the proprietor retaining the rest of the stock. ${ }^{41}$

For a while the formal statutory law did not adapt itself to this development. To the contrary, such changes as occurred in the law were responses to problems with corporations whose shares were publicly held and traded. Government policy makers were preoccupied with mounting criticism that free incorporation and general limited liability had made it both easier and more common for company promoters to swindle external investors, and they appointed the Davey Committee in 1895 as a response to this charge. ${ }^{42}$ Based on the committee's recommendations, Parliament passed the Companies Act of 1900 regulating the offering of shares to the public. The law required each company issuing such shares to publish a prospectus that would provide investors with detailed information about the enterprise. In addition, the law restricted companies' ability to allocate shares to organizers or others who did not pay for them fully in cash and required that organizers file detailed information about any

39. James B. Jefferys, Business Organisation in Great Britain, 1856-1914 (New York, 1977), 104-05. The book is a reprint of the author's 1938 University of London Ph.D. thesis entitled "Trends in Business Organization in Great Britain since 1856."

40. J. C. Stamp, British Incomes and Property: The Application of Official Statistics to Economic Problems (London, 1916), 244.

41. The House of Lords sanctioned the procedure in the famous case of Salomon v. Salomon in 1897. When Salomon initially formed Salomon Ltd. around 1895, he, his wife, and five of their children each received one $(£ 1)$ share of the company. Salomon then sold the new company his shoemaking business for $£ 20,000$ in shares (and a debenture). Eventually the business became insolvent and was liquidated. The case became famous because the House of Lords held that Salomon, the creditor of the company, was a separate entity from the company, and from Salomon, the shareholder, and thus had priority over other creditors. See Salomon v. Salomon, A.C 22 (1897).

42. Parliamentary Papers (London, 1895), vol. LXXXVIII (C. 7779), p. 151. 
such allotments as they made. It required the public registration of mortgages and other charges as a means of protecting unsecured creditors, and it mandated the circulation of audited balance sheets at annual meetings of shareholders. Finally, the law subjected directors to personal liability if they failed to conform to its provisions. ${ }^{43}$

Although the purpose of the law was to protect investors in publicly held companies, it raised the costs of organizing all types of corporations, whether they issued shares to the public or not. The law thus made the corporate form less suitable to SMEs, and not surprisingly, led to a drop in the number of companies registered from 5,082 in 1897 and 4,849 in 1900 to 3,343 in 1901 and 3,725 in $1904 .{ }^{44}$ This drop was one of the motivations for the appointment of the Loreburn/Warmington Committee in 1905. The recommendations of that committee led Parliament to enact an amendment to the Companies Act in 1907 creating the private limited company. ${ }^{45}$

It is interesting to note that the new form was not modeled on the GmbH. Although the 1895 Davey Committee had collected comparative information on organizational forms, in the case of Germany it was mainly interested in the AG and obtained only a brief description of the $\mathrm{GmbH}$, which had been introduced just three years earlier. ${ }^{46}$ Moreover, that Committee did not recommend enabling legislation for the PLLC. Intriguingly, the Loreburn/Warmington Committee of 1905, which did consider and recommend such legislation, made no reference in its report to the $\mathrm{GmbH}$ as a useful, or even as a negative, model. It took a different approach and instead simply created two separate classes of corporations. ${ }^{47}$

The 1907 Act distinguished public from private companies and subjected the former to stricter rules and higher disclosure requirements than the latter. According to Section 37(1) of the Act, a private company "means a company which by its articles" (1) restricts the right to transfer its shares; (2) limits the number of its shareholders to fifty; and (3) prohibits any invitation to the public to subscribe for any shares or debentures of the company. ${ }^{48}$ Whereas in Germany a company became private by organizing under a different law from a corporation, in Britain a company became private by including in its articles of association the above restrictions.

43. Companies Act 1900 (63 \& 64 Vict. c. 48).

44. U.K. Board of Trade, General Annual Report (London, 1923).

45. Companies Act 1907 (7 Edw. 7 c. 50).

46. Parliamentary Papers (London, 1895), vol. LXXXVIII (C. 7779), pp. 24-26.

47. Parliamentary Papers (London, 1906), vol. XLIV (Cd. 3052).

48. Companies Act 1907, section 37. 
Most other Companies Act rules applied to both public and private corporations. ${ }^{49}$ Thus business people registering under the 1907 law were offered a tradeoff. In exchange for exemption from the stringent disclosure provisions required for public companies, members of private companies had to accept restrictions on the liquidity and transferability of their shareholdings. These restrictions typically consisted of provisions that required the consent of the board or other shareholders to transfer shares or that mandated that the shares be offered to other members of the firm first. Although such provisions increased minority shareholders' vulnerability to oppression, business people could adopt governance rules that redressed the imbalance of power. The organizers of a company could opt out of the default rule (one vote per share whenever a poll was required) by including a different provision in the original articles of association, so it was possible for minority shareholders to protect themselves by increasing their voting rights or requiring supermajority votes on issues for which such a rule was not mandated by law. Subsequent alterations to the articles of association required a supermajority of 75 percent, however, as did a voluntary winding up of the company. A company could be dissolved involuntarily by the court, but only for cause-for example, inability to pay debts or a finding that it was "just and equitable" to wind up the company. ${ }^{50} \mathrm{By}$ choosing the PLLC form over the partnership, therefore, the organizers of an enterprise were reducing the possibility of untimely dissolution but also assuming greater risk of minority oppression, unless they built adequate protections into the company's initial articles of association.

Figure 2 reports the proportion of new companies that organized as corporations (public companies) compared to those that organized as PLLCs (private companies). As the figure shows, the PLLC form was enormously popular almost immediately. The number of new firms that organized as corporations averaged 4,102 from 1902 to 1906. It then dropped steeply to an average of 712 in 1912-1916, 512 in 1922-1926, 296 in 1932-1936, and thirty seven in 1942-1947. By contrast, the number of new firms that organized as PLLCs rose from average of 4,853 in 1907-1912, immediately following the legislation, to 7,936 in 1922-1926, to 12,350 in 1932-1936. During the period 1922-1926 PLLCs constituted fully 93 percent of new

49. The main exception was that the minimum number of shareholders required for a private company was only two as opposed to seven for a public company.

50. Companies (Consolidation) Act, 1908 (8 Edw. 7 Ch. 69), section 129. 


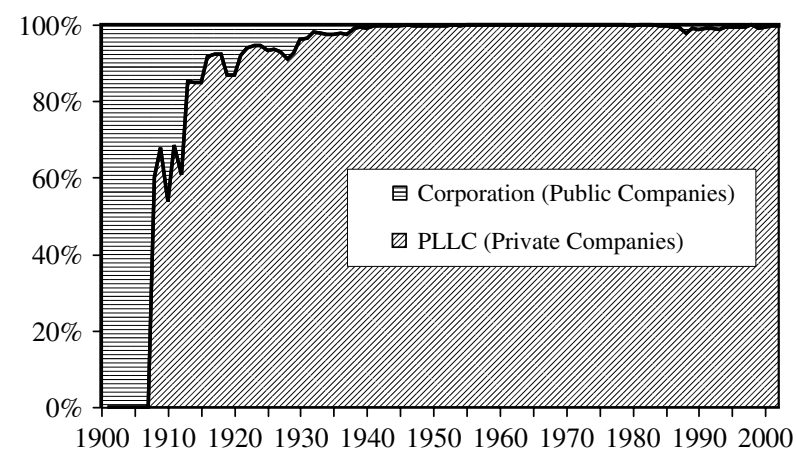

Source: U.K. Board of Trade, General Annual Report under the Companies (Winding-up) Act of 1890 (London, 1900-1921); U.K. Board of Trade, Report (London, 1922-2000).

Figure 2 Ratio of New Private to All New Limited Companies in Britain, 1900-2000.

firms taking the company form. ${ }^{51}$ Although our data do not allow us to compare the size of firms organizing as PLLCs with that of firms organizing as public companies, we note that the change in the law was accompanied by an increase in the number of small firms registering as companies. In 1901 only 34.7 percent of newly formed companies had a registered capital of $£ 5,000$ or less. In 1908 the percentage was 47.4 , and by 1936 it had risen to 76.2 . The correlation between the increase in the number of PLLCs and the rise in the number of companies with less than $£ 5,000$ in capital suggests that there was a substantial take-up of the PLLC form by small enterprises.

We do not have data on the number of new firms that formed as partnerships, so we cannot observe the effect that the advent of the PLLC had on that form. ${ }^{52}$ Nevertheless, we can guess at the magnitude of the resulting decline. If the proportions of firms organized as partnerships were similar in the United States and Great Britain, the number of partnerships formed annually in Britain should have been about 5,000 in $1908 .^{53}$ If we attribute all of the increase

51. U.K. Board of Trade, General Annual Report under the Companies (Windingup) Act of 1890 (London, 1900-1921); U.K. Board of Trade, General Annual Report (London, 1922-2000).

52. Britain also passed an enabling law for limited partnerships in 1907, but few businesses registered under that statute.

53. This number is most likely an underestimate. The U.S. Census of Manufactures reports that 62 percent of firms taking multiowner forms were partnerships in 1900 (1905, vol. 8, p. liv, Table VIII). This figure refers to the stock of firms. It is likely that partnerships' share of new firms taking multiowner forms was quite a bit higher because their life span was much shorter than corporations'. 
in the total number of new registered companies between 1907 and 1909 (about 1,000) to a decline in the formation of partnerships, we obtain an upper-bound estimate of the decline in the number of new partnerships of 20 percent. Alternatively, if we assume that the total number of multiowner firms per capita was similar in Prussia and in the United Kingdom, we can obtain an estimate of the number of new partnerships in Britain by subtracting from the projected total the actual number of registered companies. ${ }^{54}$ This procedure suggests that the number of partnerships formed in Britain declined from approximately 5,300 the year before the law to about 4,200 the year after, a drop of 21 percent. ${ }^{55}$ In Britain, unlike Germany, therefore, the PLLC seems mainly to have displaced corporations. ${ }^{56}$

\section{Organizational Choice in France}

The Code de Commerce of 1807 offered business people in France two alternatives to the ordinary partnership (or société en nom collectif). These were essentially the same choices that we have already discussed for the German case-not surprisingly, because German law was heavily influenced by the French code. As in Germany, the limited partnership (commandite simple) allowed some partners to enjoy the protection of limited liability so long as they did not play an active role in management. Limited partnerships could also have tradable shares, and in France an active market for the equities of these commandites par action enabled business people to raise capital from the broader public without obtaining the special government permission that the corporate form required.

However, applying that number to Britain, where an average of 4,200 corporations were formed annually between 1900 and 1908, gives an estimate of 6,900 new partnerships a year.

54. In 1900 Prussia had some 39 million inhabitants and Great Britain, 41 million. In January 1902 there were 896 new registrations in Prussia. Hence the total for the year was 10,700 , if we assume that January was representative.

55. France had some 39 million inhabitants and registered 6,000 new firms around 1900. Using it as a benchmark for Great Britain leads to a decline in the number of partnerships of nearly 50 percent.

56. The tax data we have from the period are consistent with this view. The number of firms filing tax returns in Britain that were not organized as private or public companies (most of them were partnerships) declined only slightly after the passage of the 1907 law, dropping from 59,227 in 1904-05 to 57,822 in 1913-14. It should be noted, however, that the tax data report changes in the stock of firms-not the number of new partnerships. Stamp, British Incomes and Property, 244. 
France adopted full general incorporation in 1867. Until that point the government had granted corporate charters sparingly, approving less than 600 between 1820 and $1867 .{ }^{57}$ Before 1857 the availability of the share commandite had muted the demand for general incorporation. In that year, however, growing complaints by minority shareholders and creditors about abuses by the commandites' general partners culminated in a set of regulatory reforms that made it much more costly to organize such enterprises. These reforms in turn led to efforts to secure more liberal incorporation rules. New legislation in 1863 permitted firms with a maximum capital of 20 million francs to organize as corporations without receiving special permission from the state. The act of 1867 removed the limit on capitalization. ${ }^{58}$

As was the case for Germany, we can track the organizational choices made by French firms because they were required to file their articles of association with a local commercial tribunal. As figure 3 shows, after 1867 the corporation slowly grew in popularity until it accounted for about 20 percent of new registrations in the 1910s. This slow take-up rate (relative to Anglo-Saxon countries) might tempt one to think that French law placed a high fiscal and regulatory burden upon corporations and thus discouraged their formation, but there is little evidence for such a view. The taxes that firms paid did not differ across organizational forms until after World War II, and the additional disclosure requirements that corporations had to meet were modest. Corporations that raised capital from the public had to issue a prospectus and file a copy of their articles of association, a list of their initial shareholders, and the minutes of their first shareholders' meeting. But partnerships also had to register a list of their members and file a copy of their articles of association. Registration fees were essentially the same across organizational forms. Although it was more common for corporations to have their articles of association notarized (a process that cost 1 percent of capital), this extra step was not required by law. It is likely, therefore, that the limited take-up of corporations can be explained by the availability of alternative forms, such as the limited partnership form, and also by the greater flexibility that business people in France had to modify the partnership contract to control their liabilities and concentrate managerial authority.

As the popularity of corporations grew, ordinary partnerships became relatively less common, but they still accounted for at least

57. Freedeman, Joint-Stock Enterprise in France, 27, 67, 81, 116.

58. Freedeman, Joint-Stock Enterprise in France; and Freedeman, Triumph of Corporate Capitalism in France. 


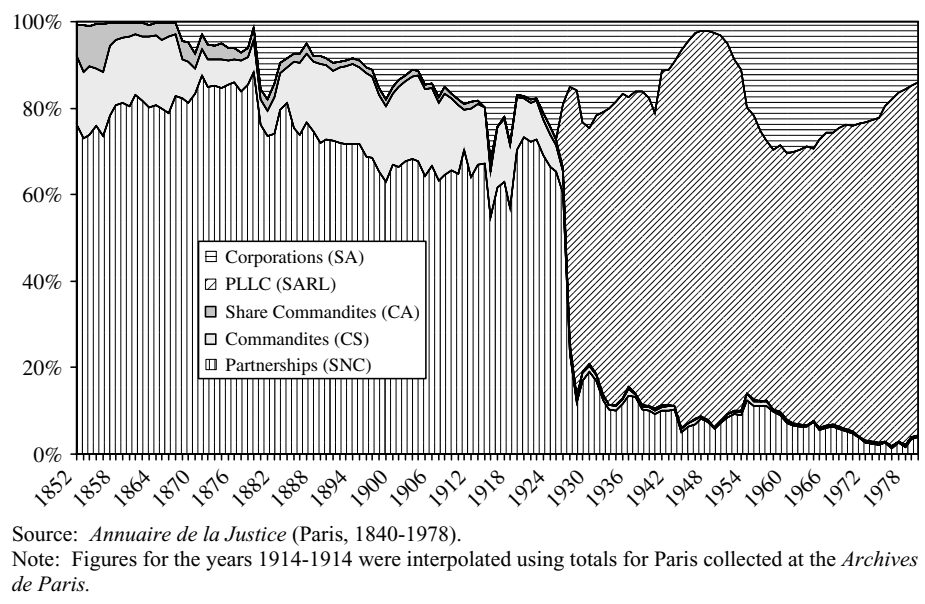

Figure 3 Distribution of New Firms Among Multi-Owner Organizational Forms, France, 1852-1978.

60 percent of all new firms. Some of the decline in partnerships, moreover, reflected the renewed popularity of the commandite simple at the end of the nineteenth century. Commandites par action suffered a permanent decline but, even though they might be considered inferior substitutes for the corporation, did not completely disappear. For example, Schneider, the large iron and steel works, remained a commandite par action until the 1960s, and Michelin is still one today.

Despite ongoing debate over the desirability of reforming France's general incorporation law, little changed between 1867 and 1925. The two main issues seem to have been requiring greater accounting transparency for publicly traded firms and limiting the possibility of fraud when shares were issued to the public. A detailed set of reform proposals drawn up in 1903 went nowhere. ${ }^{59}$ However, the end of World War I and the return of Alsace and Lorraine created an impetus for innovation. Business people in the recovered territories had been able to avail themselves of the $\mathrm{GmbH}$ statute since 1892. There were at least $400 \mathrm{GmbHs}$ operating in Alsace and Lorraine, and their owners showed little interest in converting to partnerships, commandites, or corporations. ${ }^{60}$ Instead, they pressured Paris to enact an enabling law for GmbHs. In 1919 a bill that essentially translated the $\mathrm{GmbH}$ statute

59. Charles Lyon-Caen and Louis Renault, Manuel de droit commercial (y compris le droit maritime) (Paris 1924).

60. Documents Parlementaires, 3348 (Nov., 1921). 
into French was introduced in the Assembly, but it faced staunch chauvinistic opposition and was withdrawn almost immediately: after four years in the trenches the victors did not want to imitate the losers. Although business people in Alsace and Lorraine were disappointed, the failure to pass a law galvanized more widespread support for reform. Local chambers of commerce throughout France urged the passage of some version of the legislation, and a new bill was introduced in 1921 to create the SARL. For reasons that remain unclear, the bill lay dormant until 1925, when it was approved by a unanimous voice vote in the Assembly. After an expedited procedure, it was also unanimously approved in the Senate. Whatever the politics that led to the adoption of the law, when French legislators finally acted, they charted a course that was substantially different from that of either Germany or Britain. ${ }^{61}$

A SARL was created when legally valid articles of incorporation (Statuts) were entered in the relevant commercial register. Any enterprise that satisfied the registration requirements could become a SARL with the exception of holding companies in insurance and finance. ${ }^{62}$ As in the German case there was emphasis on reducing disclosure and transactions costs. Hence although firms had to register, their articles of association could be drawn up by private agreement-without the burden of notary fees. As in Germany there was a minimum capital, 25,000 francs, that had to be divided into shares of 100 francs or more each. Given the low value of the franc, this constraint was not onerous. Indeed, during the inflationary 1920s, 25,000 francs was less than five times per capita income. ${ }^{63}$

Unlike partnerships, SARLs were joint-stock firms. As a result, they were not dissolved by the death of an associate; the share simply passed on to member's heirs. Nor could a SARL be dissolved simply by the desire of a member to withdraw. SARLs thus seem to have solved

61. The various proposals can be found in Documents Parlementaires, 3348 (Nov., 1921); and Georges Ripert, Traité élémentaire de droit commercial (6th ed., Paris, 1967-1970), vol. 1, pp. 476-78.

62. Similar restrictions were added later to bar banks (1941), certain firms in the entertainment industry (1945), and mutual funds (1957) from organizing as SARLs. Any enterprise that organized as a SARL was automatically a commercial firm (société de commerce) regardless of what it actually did. Hence it was governed by the commercial rather than civil code. Moreover, its tax status was that of a partnership. Ripert, Traité élémentaire de droit commercial, vol. 1, p. 483.

63. Law of March 7, 1925, Code de commerce, suivi des lois commerciales et industrielles, avec annotations d'après la doctrine et la jurisprudence et renvois aux publications Dalloz (63rd ed., Paris, 1967), 800-06. The defense of the proposed law can be found in Documents Parlementaires, Annexe 712, Session of 12-16-1924, pp. 691-99. 
the main problem faced by French partnerships: impermanence. As was the case for the $\mathrm{GmbH}$ and the private limited company in Britain, shares of SARLs could not be publicly traded. The French went further, however, and required private sales of equity to be approved by the other shareholders. From 1925 to 1966 the owners of a quarter of the shares could veto any trade. Unlike the German case, if a trade was approved, the sale could be finalized without recourse to a notary. ${ }^{64}$

As a general rule, shareholders in SARLs were more at risk of minority oppression than was the case for GmbHs in Germany or private limited companies in Britain. SARLs had to follow strict oneshare-one-vote rules. ${ }^{65}$ Unless all members of the firm owned the same number of shares, it was not possible to structure an SARL like a partnership where all owners had equal control rights. SARLs could be set up so that managers were elected by, and served at the pleasure of, the majority of shareholders. But if the managers were named in the articles of association, they could not be removed except through litigation. $^{66}$

Most subsequent changes in legal rules have focused on the extensive powers of management in SARLs. In the early years after the act's passage, judges established precedents for removing entrenched managers, essentially creating standards whereby incompetent or fraudulent managers could be dismissed. Intervention by the legislative branch was largely limited to reinforcing these judicially imposed penalties for fraud, in particular with respect to bankruptcy cases. ${ }^{67}$ In 1966, however, a major reform did away with the option of creating irrevocable managers. Managers could now be removed,

64. In 1966 the shareholders' veto power was transformed into a preemption right (article 45 of the law of July 24 1966). Ripert, Traité élémentaire de droit commercial, vol. 1, p. 498.

65. Corporations could choose any voting scheme they wanted, including minimum shareholding requirements to participate in the general meeting, graduated voting scales, and multiple classes of shares. These rules had to be published in the firm's prospectus and validated at the first shareholders' meeting. By 1966 only two deviations were allowed from one share one vote: stockholders owning less than ten shares could be excluded from general meetings; and stockholders who had owned their shares at least two years could be given double voting rights. See Article 27 of the law of July 24, 1867, in Code de commerce (1967), 770.

66. Law of March 7, 1925, article 24, Code de commerce (1967), 1051-55. See also Ripert, Traité élémentaire de droit commercial, vol. 1, pp. 476-78.

67. Ripert, Traité élémentaire de droit commercial, vol. 1, p. 477. 
though only for cause, with the list of permissible reasons echoing the judicial standards put in place earlier in the century. ${ }^{68}$

As figure 3 shows, once the form became available in 1925, SARLs very quickly accounted for the vast majority of new enterprises registered in France. The form seems to have been particularly attractive to firms that had small numbers of investors but whose capital requirements were much larger than those of most partnerships. In 1927, for example, 57 percent of the firms that organized as SARLs had only two associates, but the average capital of new SARLs was more than twice that of new partnerships (including limited as well as ordinary). SARLs were much smaller (in terms of capital) than the relatively few corporations that continued to form. In 1927, their average capital was less than a quarter that of new SAs, and only 10 percent of the SARLs organized in that year had a capital as large as the median SA formed in the same period. The median capital of new SARLs was 100,000 francs, four times the minimum required by the law. ${ }^{69}$

Unlike in Germany, the enactment of enabling legislation for SARLs significantly reduced the number of new corporations. This result is not at all surprising because the high cost of incorporation in Germany meant that only those enterprises that could really benefit from the corporation's advantages bothered to take out charters. Also unlike Germany, the advent of the SARL led French business people to all but abandon the limited partnership form. This result too is not surprising if one considers the position of managers with only minority stakes in their enterprises. Because such managers had to worry about whether they would be pushed out by dominant shareholders, in Germany the $\mathrm{GmbH}$ had relatively little appeal compared to a KG because shareholders in a $\mathrm{GmbH}$ could dismiss a manager at will. By contrast, managers in a similar position in France could entrench themselves in a SARL by registering their names along with the firm's articles of association. Hence the SARL had a greater effect on the use of the commandite form than the $\mathrm{GmbH}$ had on the KG. Partnerships also experienced a much more dramatic collapse in France than in Germany, with new registrations in the former country falling as much as 90 percent by the mid 1930s. Part of the explanation may be the more stringent minimum capital requirement for the GmbH. Firms with capitalizations below 20,000 Marks had no choice in Germany

68. Law of June 24, 1966, article 55, Code de commerce (1967), 868-69. See also Ripert, Traité élémentaire de droit commercial, vol. 1, pp. 504-05.

69. Tribunal de Commerce, Greffe du Tribunal, Enregistrement des Sociétés, Serie D32U3, registers 110-113, 115-117, 169, Archives de Paris. 
but to organize as partnerships, and as we have seen this constraint seems to have been binding.

\section{The U.S. Outlier}

The corporate form came relatively early to the United States. Moreover, in contrast to the German and British experiences, the fees and disclosure requirements associated with organizing a corporation generally became less rather than more burdensome over the course of the nineteenth and early twentieth centuries, so there was no similar impetus to create a form that gave enterprises the advantages of incorporation without imposing heavy organizational costs. ${ }^{70}$ For all practical purposes, therefore, business people in the United States had only two choices: they could organize as partnerships or they could take out corporate charters. They could not trade off some of the advantages and disadvantages of each form but had to choose one or the other. That is, they had to choose either to bear the risk of untimely dissolution or suffer the possibility of minority oppression.

The continued popularity of partnerships in the United States deep into the twentieth century suggests that the disadvantages of the corporate form weighed heavily on SMEs. Data from the Census of Manufacturers show that as late as 1900 more than 60 percent of firms taking multiowner forms organized as partnerships. Although the proportion of partnerships fell over time as the scale of enterprise rose, dropping to about 40 percent of firms taking multiowner forms by 1920, partnerships retained considerable importance in the economy as a whole. ${ }^{71}$ Indeed, according to Internal Revenue Service (IRS) data, they constituted more than 60 percent of all firms taking multiowner forms as late as 1947. Although, as table 2 shows, the proportion organized as partnerships varied across industry groups, even in the manufacturing sector the figure still hovered around 40 percent. By the

70. See Arthur K. Kuhn, A Comparative Study of the Law of Corporations with Particular Reference to the Protection of Creditors and Shareholders (New York, 1912); John W. Cadman, The Corporation in New Jersey: Business and Politics, 1791-1875 (Cambridge, Mass., 1949); Christopher Grandy, "The Economics of Multiple Governments: New Jersey Corporate Chartermongering, 1875-1929" (Ph.D. diss., University of California, Berkeley, 1987); William G. Roy, Socializing Capital: The Rise of the Large Industrial Corporation in America (Princeton, N.J., 1997).

71. The data from the Census of Manufactures are analyzed in Lamoreaux and Rosenthal, "Contractual Tradeoffs and SME's Choice of Organizational Form." 
Table 2 Distribution of Partnerships and Corporations in the United States, by Industry, 1947 and 1997

\begin{tabular}{lrrrc}
\hline Industry & Year & $\begin{array}{c}\text { Number of } \\
\text { Partnerships }\end{array}$ & $\begin{array}{c}\text { Number of } \\
\text { Corporations }\end{array}$ & $\begin{array}{r}\text { Corporations } \\
\text { as Percent of } \\
\text { Multiowner } \\
\text { Forms }\end{array}$ \\
\hline All & & & & 0.38 \\
Agriculture, forestry, & 1947 & 888,862 & 551,807 & 0.73 \\
and fishing & 1997 & $1,758,627$ & $4,710,083$ & 0.06 \\
Mining & 1997 & 120,402 & 7,329 & 0.56 \\
& 1947 & 13,579 & 163,114 & 0.38 \\
Construction & 1997 & 28,045 & 32,996 & 0.54 \\
& 1947 & 52,592 & 20,287 & 0.28 \\
Manufacturing & 1997 & 72,098 & 487,783 & 0.87 \\
& 1947 & 74,978 & 112,184 & 0.60 \\
Transportation, & 1997 & 40,022 & 325,045 & 0.89 \\
communications, & 1947 & 20,776 & 23,729 & 0.53 \\
and utilities & 1997 & 30,917 & 209,402 & 0.87 \\
Wholesale and & 1947 & 372,212 & 177,297 & 0.32 \\
retail trade & 1997 & 173,009 & $1,149,132$ & 0.87 \\
Finance, insurance, & 1947 & 87,647 & 151,043 & 0.63 \\
$\quad$ and real estate & 1997 & 974,223 & 744,545 & 0.43 \\
Services & 1947 & 130,954 & 45,975 & 0.26 \\
Other & 1997 & 310,990 & $1,592,854$ & 0.84 \\
& 1947 & 15,722 & 5,669 & 0.27 \\
\hline & 1997 & 2,263 & 5,201 & 0.70 \\
\hline
\end{tabular}

Source: Susan Carter, et al., Historical Statistics of the United States: Millennial Edition (New York, 2006), vol. 3, Tables Ch 1-192.

end of the twentieth century, however, the balance had shifted. For the economy as a whole fully 73 percent of firms taking multiowner forms were corporations by 1997, and the proportion in manufacturing was 89 percent.

The increase in the second half of the twentieth century in the proportion of firms organized as corporations suggests that the form became more suitable to SMEs during this period. As we shall see, changes in state incorporation laws during the third quarter of the twentieth century increased the flexibility of the form, enabling "close corporations" to adopt governance rules that mimicked those of PLLCs. The intriguing question is why these changes were so late in coming. Why did SMEs in the United States have to wait more than a half century after their German counterparts to secure the advantages of the PLLC form?

As a matter of fact, there was an attempt to introduce the PLLC form in the United States even earlier than in Germany. The origins of this effort are murky, but it seems to have been triggered by a debate during the 1870s in Pennsylvania's constitutional convention over 
whether the state's general incorporation laws should be liberalized or made more restrictive. In 1874 the Pennsylvania legislature passed two statutes that appealed to opposing sides of that discussion. One increased the liability of shareholders in corporations to double the par value of their shares. The other gave any three or more persons engaged in "any lawful business or occupation" the opportunity to organize as a "partnership association," a legal entity whose shares were not tradable but whose "capital shall alone be liable for the debts of such association." In other words, it gave them the opportunity to organize a PLLC. Similar enabling legislation for partnership associations was soon adopted in Michigan (1877), New Jersey (1880), and Ohio (1881). Virginia also passed a statute in 1874 but repealed it in $1918 .^{72}$

Partnership associations, like GmbHs and SARLs, could be formed simply by filing a document with a local (in this case county) official. The association had to include the word "limited" in its name and to register its name, total capital, and duration (which could not exceed twenty years), the names of its members, the amount of capital subscribed by each member (including the value of any contributions made in the form of real or personal property), and the names of the officers of the association. Any subsequent changes to these arrangements also had to be registered. A partnership association could only be dissolved before the end of its term by vote of a majority of the associates in number and value of interest, so its members were largely protected from the problem of untimely dissolution. This advantage over ordinary partnerships came at the cost of some increased danger of minority oppression, however, because management was concentrated in a board of managers elected annually by the members. The flexibility that partnerships

72. Pennsylvania also subsequently passed enabling legislation for another form of PLLC, the so-called registered partnership, whose provisions were even more liberal. Warren, Corporate Advantages Without Incorporation, ch. 4; L.I.M., "Notes: Business Associations in Pennsylvania," University of Pennsylvania Law Review 82 (Dec. 1933): 153; George E. Stransky, Jr. "The Limited Partnership Association in New Jersey,” Rutgers Law Review 10 (Summer 1956): 701-02; James A. Matthews, Jr., "Comments: Business Associations-Registered Partnership, Partnership Association or the Corporation-Selection of the Suitable Form in Pennsylvania," Villanova Law Review 2 (April 1957): 386-87; Schwartz, "The Limited Partnership Association,” 30-33; Wayne M. Gazur and Neil M. Goff, "Assessing the Limited Liability Company," Case Western Reserve Law Review 41, no. 2 (1991): 393-94. These laws and subsequent amendments passed through 1899 are available in the microfilm collection Session Laws of American States and Territories. All references to specific legislation below refer to this collection and are cited simply by date. 
associations had to adopt voting rules that protected the interests of minority shareholders varied somewhat from state to state. Whereas associations in New Jersey and Ohio could adopt whatever voting rules they wished, a supplement to the Pennsylvania law specified that managers were to be elected by a majority in value of interest. ${ }^{73}$ Regardless, minority shareholders always had the ability to exit if they disagreed with the actions of the majority. Although individuals who purchased shares could only participate in the business of the association if a "majority of the members in number and value of their interests" so voted, any transferee not admitted to the business would be reimbursed for his or her shares at a price that was either mutually agreed upon or, if no agreement could be reached, determined by the local Court of Common Pleas.

Although passage of the Pennsylvania statute led an initial wave of firms to adopt the PLLC form, including some famous enterprises such as the Carnegie Steel Company, Ltd., there is abundant evidence that the partnership association did not catch on in the United States. In the first place, it did not spread beyond the initial group of states. In the second, it generated relatively little case law. Most of the litigation involving partnership associations arose in Pennsylvania and Michigan, but even in these states the number of cases was low. In New Jersey, there were only about five cases over the next century. ${ }^{74}$ Third, periodic law-review articles called attorneys' attention to this "hidden" form and reminded them that it had the potential to help business people solve the contracting problems they confronted in choosing between partnerships and corporations. But these efforts seem to have had little effect. ${ }^{75}$ About two decades after one such

73. The Pennsylvania voting rule was imposed on June 8, 1895. The original legislation of June 2, 1874 left the question open, as did the laws of New Jersey (March 12, 1880) and Ohio (April 20,1881). In all three states minority shareholders received additional protection from provisions in the original laws that made it illegal for any association to "loan its credit, its name or its capital" to any member of the association. A May 10, 1889 amendment to the Pennsylvania law further limited the potential for minority oppression by declaring that (after the association had been in business for five years) its officers could not receive in compensation for their services "a sum in the aggregate greater than the amount of net earnings actually earned" during the previous year without the consent of "two thirds of all the members of the association."

74. Stransky, "The Limited Partnership Association in New Jersey," 701; Schwartz, "The Limited Partnership Association," 31. According to Warren, not much advantage of the form "seems to have been taken in New Jersey, Ohio or Virginia.” Corporate Advantages Without Incorporation, 523.

75. L.I.M., "Business Associations in Pennsylvania”; Stransky, "The Limited Partnership Association in New Jersey"; Matthews, "Business Associations"; Schwartz, "The Limited Partnership Association." 
article was published, another writer found that in New Jersey only about 20 to 50 partnership associations were formed each year in populous Essex County, about three a year in Union County, and virtually none in Camden, Burlington, and Gloucester Counties. ${ }^{76}$ Another author surveyed lawyers practicing in Pennsylvania in the mid 1950s and found that they rarely advised their clients to organize partnership associations. ${ }^{77}$

An important factor inhibiting the use of the new form was the conservative character of the common law. Because precedents are so important in deciding court cases, business people hesitate to adopt new organizational forms until there is a substantial body of case law establishing the extent to which and how essential contractual provisions will be enforced. ${ }^{78}$ But a substantial body of case law cannot be amassed unless enough businesses adopt the form to yield some litigation. This "Catch 22" situation makes it difficult to introduce new organizational forms in common-law countries. To make matters worse, when cases did come before the courts, judges interpreted the statutes in ways that made partnership associations a risky way of obtaining limited liability. In a series of important cases, for example, the Pennsylvania court determined that if the registration document filed by a partnership association was incorrect in some material respect, or if the list of the association's capital made it "difficult to judge of values" by lumping different items together, the association in effect had never formed and its members were fully liable for their enterprise's debts. ${ }^{79}$ The court acknowledged that the rule for corporations was just the opposite, but it justified the distinction by highlighting the ways in which partnership associations differed from corporations. Although for convenience, partnership associations were "clothed with many of the features and powers of a corporation,... no man can purchase the interest of a member and

76. Nearly half of 50 partnership associations organized in Essex County in 1954 were in real estate. Stransky, "The Limited Partnership Association in New Jersey,"' 715.

77. Matthews, "Business Associations," 395.

78. According to Stransky ("The Limited Partnership Association in New Jersey," 710), "New Jersey attorneys can't be sure how the courts of their own state will react to certain situations. There are far too many statutory provision which have not been judicially construed."

79. For example, the court found the following impermissibly vague: "furniture, fixtures and all the goods, tools and chattels now on the premises of 208 Lackawanna avenue, Scranton city, now leased by said Martin Maloney, valuation $\$ 12,500 . "$ Maloney v. Bruce, 94 Pa. 249 (1880). See also Appeal of Hite Natural Gas Co., 118 Pa. 436 (1888); Vanhorn v. Corcoran, 127 Pa. 255 (1889); Sheble v. Strong, 128 Pa. 315 (1889); Gearing v. Carroll, 151 Pa. 79 (1892). 
participate in the subsequent business, unless by a vote of a majority of the members in number and value of their interests." The state did not grant a partnership association a charter; its privileges rested entirely on the statement submitted at the time of registration. As a result, it was "competent" for a plaintiff suing for payment of a debt "either to point to a fatal defect" in the statement "or to prove that an essential requisite, though formally stated, is falsely stated." 80

This conservative tendency of the courts was exacerbated in the United States by the decentralized character of business law. Organizational forms were governed by the states, not the federal government, though businesses often operated in many states at the same time. As a consequence, there was a great deal of uncertainty about how business forms developed in one state would be interpreted by the courts of another. In a Massachusetts case, for example, a Pennsylvania partnership association was held to be an ordinary partnership whose members bore full unlimited liability. ${ }^{81}$

British companies, of course, were spared the uncertainties of federalism, but they could not escape the conservatism of the common law. The longstanding hostility of the courts to limited partnerships may explain why a 1907 law enabling that form had little consequence. ${ }^{82}$ By contrast, the 1907 statute for private limited companies was successful because it was such a modest innovation. In effect all that the law did was exempt SMEs from the burdensome regulatory requirements that Parliament had imposed to prevent abuses by companies whose shares were publicly traded. Businesses that organized as private limited companies still benefited from a half century or more of case law on corporations.

The modification of state corporate statutes that occurred in the United States during the second quarter of the twentieth century

80. Eliot v. Himrod, $108 \mathrm{~Pa}$. 569, 580-81 (1885). Similar strictures had essentially killed the limited partnership form in the United States, and the lower court in this case had attempted to prevent partnership associations from suffering a similar fate by making the case that the legislature intended them to be treated like corporations rather than as limited partnerships. But the lower court was overruled on appeal.

81. Edwards v. Warren Linoline \& Gasoline Works, 168 Mass. 564 (1897); Stransky, "The Limited Partnership Association in New Jersey," 709-10; Warren, Corporate Advantages Without Incorporation, 517- 19.

82. Only 144 limited partnerships were formed in the first year after the enabling law, but even this number was large compared to the future take-up of the form. The average annual number of new limited partnerships in the years 1911-20 was about fifty, and in the decade 1921-30 only thirty seven. U.K. Board of Trade, General Annual Report under the Companies (Winding-up) Act of 1890 (London, 1900-1921); U.K. Board of Trade, General Annual Report (London, 1922-1930). 
was much more successful at providing business people with the advantages of PLLCs than the early partnership association statutes had been. The impetus for the change seems to have come from the high level of personal relative to corporate income taxes in the postWorld War II period. Corporations paid a flat tax on their income that dropped from a post-World War II peak of 52 percent to 46 percent on the eve the Tax Reform Act of 1986. Rates for the top personal income tax brackets were above this level (often substantially) during these years. ${ }^{83}$ In addition, whereas the flat corporate tax rate was unaffected by inflation, the progressive personal income tax subjected individual tax payers to bracket creep, forcing marginal rates relatively higher. In 1950 the amount of revenue raised by the corporate and personal income taxes had been about the same; by 1980 the personal income tax yielded four times the revenue of the corporate tax. ${ }^{84}$

Not surprisingly, during this period business people increasingly chose to organize their enterprises as corporations rather than partnerships (tables 2 and 3). Moreover, perhaps because this shift created the critical mass needed to push for change, states began to modify their laws to make the corporate form more suitable for SMEs. ${ }^{85}$ The first significant break occurred in North Carolina in 1955. Imbedded in that state's new Business Corporation Act were several provisions aimed specifically at small, closely held firms, including one declaring that agreements among all the shareholders of such corporations shall not, regardless of their form or purpose, "be invalidated on the ground that [their] effect is to make the parties partners among themselves." The North Carolina statute also contained a provision that made it possible for any stockholder to precipitate a judicial dissolution if the corporation's charter or

83. Corporations were also subject to double taxation to the extent that shareholders had to pay taxes on earnings they received in the form of dividends. So if corporate and personal tax rates were the same, partnerships would have a tax advantage.

84. W. Elliot Brownlee, Federal Taxation in America: A Short History (New York, 1996), 89-129.

85. Certainly, during this period one finds for the first time a surge of law review articles and similar publications whose purpose was (1) to inform attorneys about the types of provisions they could imbed in corporate articles of association to protect investors, and (2) to push for new legislation increasing the flexibility of the corporate form. See especially the work of F. Hodge O'Neal, including “Giving Shareholders Power to Veto Corporate Decisions: Use of Special Charter and By-Law Provisions," Law and Contemporary Problems 18 (Autumn 1953): 451-72; "Developments in the Regulation of the Close Corporation," Cornell Law Quarterly 50 (Summer 1965): 641-62; “Close Corporations: Existing Legislation and Recommended Reform,” Business Lawyer 33 (Jan. 1978): 873-88; and Close Corporations: Law and Practice, 2 vols. (Chicago, 1958). 
Table 3 Distribution of Organizational Forms in the United States, 1949 to 2002

\begin{tabular}{cccc}
\hline Year & Partnerships & Corporations & LLCs \\
\hline 1949 & 61 & 39 & - \\
1963 & 41 & 59 & - \\
1979 & 34 & 66 & - \\
1993 & 26 & 73 & 1 \\
2002 & 18 & 70 & 12 \\
\hline
\end{tabular}

Sources: Carter, et al., Historical Statistics of the United States, vol. 3, Tables Ch 193-204; SOI Bulletin, various issues.

Note: The figures for ordinary partnerships include limited partnerships. Their proportion of multiowner forms has grown in recent years from about 4 percent in 1993 to about 6 percent in 2002, so the table understates the drop in ordinary partnerships.

any other written agreement among all the shareholders entitled "the complaining shareholder to liquidation or dissolution of the corporation at will or upon the occurrence of some event which has subsequently occurred." 86 In other words, North Carolina's law now permitted members of corporations to protect themselves against minority oppression by assuming a greater risk of untimely dissolution. About a dozen other states passed similar statutes over the next thirty years, and still others modified their corporate statutes in ways that increased the flexibility of the form. ${ }^{87}$

Legislation during Ronald Reagan's presidency reversed the tax calculus, first in 1981, by reducing the top personal tax rate to 50 percent, and then, with the Tax Reform Act of 1986, by reducing it to 28 percent (the 1986 Act also dropped the corporate rate from 46 to 34 percent). Again these changes seem to have provided the impetus for legislative innovation. After the IRS determined in 1988 that firms organized as Limited Liability Companies (LLCs) under a Wyoming statute would be taxed as partnerships, other states quickly passed similar laws, explicitly writing the bills to conform to the terms of the ruling. ${ }^{88}$ The impact of these changes on business people's

86. O’Neal, "Developments in the Regulation of the Close Corporation,'”647-48.

87. Kelvin H. Dickinson, "Partners in a Corporate Cloak: The Emergence and Legitimacy of the Incorporated Partnership," American University Law Review 33 (Spring 1984): 559-600; O’Neal, "Developments in the Regulation of the Close Corporation," and "Close Corporations."

88. The original Wyoming law was essentially a private bill passed to accommodate a particular oil company. See Robert R. Keatinge, et al., "The Limited Liability Company: A Study of the Emerging Entity," Business Lawyer 47, no. 2 (1991-92): 381-84; Peter D. Hutcheon, "The New Jersey Limited 
organizational choices was to some extent counteracted, however, by legislation liberalizing the rules under which small corporations could claim Subchapter S status, which allowed them to be taxed as partnerships. ${ }^{89}$

There is no information on the number of businesses that organized under the close corporate statutes passed during the third quarter of the twentieth century or that took advantage of the increased contractual flexibility offered by many states' modifications of their general incorporation laws. We do know, however, that the proportion of firms taking multiowner forms that were organized as partnerships dropped from 60 percent in 1949 to 34 percent in 1979 (table 3). Although this decline could be taken as evidence that businesses responded to this liberalization by shifting toward the corporate form, the fall could also have resulted from the more favorable tax treatment afforded corporations during those years. We also know that business people displayed considerable enthusiasm for the new LLC form by the end of the twentieth century. According to the IRS, in 1993 (the first year for which figures are available), there were only about 17,000 LLCs in the United States. By 1997 the number was nearly 350,000, and by 2002 it exceeded 946,000. There is no way of knowing what proportion of new firms organized as LLCs, but in 2002 LLCs constituted 12 percent of all multiowner enterprises in the U.S. economy, up from around considerably less than 1 percent in 1993. Most of this gain seems to have come at the expense of ordinary partnerships, whose proportion of the total declined from 22 percent in 1993 to 12 percent in 2002 (the share of

Liability Company Statute: Background and Concepts," Seton Hall Legislative Journal 18, no. 1 (1993): 117-21; Gazur and Goff, “Assessing the Limited Liability Company,” 390. A second wave of statutes for Limited Liability Partnerships (LLPs) quickly followed. Although the initial Texas legislation creating the LLP form was apparently "a response to astronomical losses threatening lawyers and accountants as a result of their partners' involvement in the savings and loan crises of the late 1980s," Fallany O. Stover and Susan Pace Hamill have argued that the rapid spread of the form to other states owed more to tax considerations. See "The LLC Versus LLP Conundrum: Advice for Businesses Contemplating the Choice," Alabama Law Review 50 (Spring 1999): 813-47. Additional statutes enacted around the same time further expanded the menu of options. The most notable was Delaware's 1988 law on statutory business trusts which gave business people an extraordinary degree of contractual freedom in organizing their enterprises. The legislation did not even specify any default provisions. See Hansmann, Kraakman, and Squire, "Law and the Rise of the Firm," 1397.

89. Brownlee, Federal Taxation in America, 130-55; Thomas B. Petska and Robert A. Wilson, “Trends in Business Structure and Activity, 1980-1990," SOI Bulletin 13 (Spring 1994): 27-72; and Petska, "Taxes and Organizational Choice: An Analysis of Trends, 1985-1992,’' SOI Bulletin 15 (Spring 1996): 86- 102. 
limited partnerships actually increased from about 4 to 6 percent). By contrast, the proportion of multiowner firms organized as corporations dropped only slightly, from 73 percent in 1993 to 70 percent in 2002 . The relatively small decline in the proportion of corporations suggests that the changes states made to their incorporation statutes after World War II did in fact considerably increase business people's contractual freedom, remedying most of the disadvantages of corporations that had enabled partnerships to remain so popular for so long.

\section{Conclusion}

Most studies of organizational forms recount the history of the corporation in the United States and then track the diffusion of this form to the rest of the world, giving high marks to countries that passed general incorporation laws early on and low marks to those that were late in enacting this important legislation. In this article, we have taken a different tack. Although we recognize that most very large enterprises are best organized as corporations, we argue that the corporate form has disadvantages that limit its utility for many SMEs. SMEs may be better off, we suggest, if they can adopt a more flexible form of organization that allows them to trade off the advantages and disadvantages of both corporations and partnerships as suits their particular type of business. The PLLC was such a form, and the bulk of our article is devoted to tracing its emergence and diffusion first in Germany, then in Britain and France, and finally in the United States.

In challenging the conventional idea that the corporation is a globally superior form of business organization, we have also cast doubt on the related notion that Anglo-American legal institutions are superior to French and German ones-that is, that common-law regimes provide an inherently better environment for business than the code-based legal regimes of the European continent. If one looks at history from the vantage point of the PLLC rather than the corporation, then Germany, a code-based country, was the key legal pioneer, with Britain, a common-law country, following a decade and a half later. France, a code-based country, was a distant third, but if rapidity of diffusion is a good indicator of a form's ability to satisfy businesses' contracting needs, then France may have been the most successful innovator. Ultimately, U.S. enterprises obtained a similar degree of contractual freedom, but not until the second half of the twentieth century. For most of U.S. history the common law's reliance on precedent, in combination with the peculiarities of federalism, seems to have constrained legal innovation. As a result, businesses were 
forced to make do with a much more limited set of organizational options than their European counterparts until the second half of the twentieth century.

Despite its suboptimal menu of organizational forms, the U.S. economy was extraordinarily successful. The lack of alternatives to the standard partnership and corporation may have imposed costs in the form of profits lost to untimely dissolution or firms that did not organize because investors feared minority oppression, but these costs neither prevented the economy from growing rapidly nor precluded the emergence of a vibrant SME sector. Nonetheless, the limited menu of business forms may have mattered in other ways. It may have affected the size distribution of firms in particular industries, for example, or even the relative performance of certain kinds of enterprises across countries. We are currently collecting the data that will enable us to explore these possibilities. In other work, moreover, we have modeled the tradeoffs involved in the choice of organizational form and found that the transaction costs we have highlighted were most likely to have adverse affects in circumstances where firms' rates of profit were likely to be low. ${ }^{90}$ Everything we know about the U.S. economy in the late nineteenth and early twentieth centuries - the rapid population growth, fall in transportation and communication costs, settlement of the continent, discovery of raw material resources, and dramatic pace of technological change-suggests that high profit opportunities were abundant. As a result, policy makers who recommend that developing countries follow the U.S. model may be doing them a disservice. Without such a rich set of investment opportunities, transaction costs are more likely to bind, and business people may be better off with the more extensive menu of options provided by French or German law. Moreover, as we have seen, in recent years U.S. law has converged toward that of France and Germany, rather than the reverse.

Bibliography of Works Cited

Books

Berle, Adolf A., Jr., and Gardiner C. Means. The Modern Corporation and Private Property. New York, 1933.

Brownlee, Elliot W. Federal Taxation in America: A Short History. New York, 1996.

90. See Lamoreaux and Rosenthal, "Corporate Governance and the Plight of Minority Shareholders," and "Contractual Tradeoffs and SME's Choice of Organizational Form." 
Burhop, Carsten. Die Kreditbanken in der Gründerzeit. Stuttgart, 2004.

Cadman, John W. The Corporation in New Jersey: Business and Politics, 1791-1875. Cambridge, Mass., 1949.

Carter, Susan, et al. Historical Statistics of the United States: Millennial Edition. 5 vols. New York, 2006.

Chandler, Alfred D., Jr. The Visible Hand: The Managerial Revolution in American Business. Cambridge, Mass., 1977.

Clark, Robert C. Corporate Law. Boston, 1986.

Crüger, Hans. Die Gesellschaft mit beschränkter Haftung. Berlin, 1912.

Fogel, Robert W. Railroads and American Economic Growth: Essays in Econometric History. Baltimore, Md., 1964.

Freedeman, Charles E. Joint-Stock Enterprise in France, 1807-1867: From Privileged Company to Modern Corporation. Chapel Hill, N.C., 1979. The Triumph of Corporate Capitalism in France, 1867-1914. Rochester, N.Y., 1993.

Guilini, Edgar. Die Gesellschaft mit beschränkter Haftung nach Vereinigung aller Geschäftsanteile in einer Hand. Heidelberg, 1919.

Hachenburg, Max. Staub's Kommentar zum Gesetz, betreffend die Gesellschaften mit beschränkter Haftung. 4th ed. Berlin, 1913.

Harris, Ron. Industrializing English Law: Entrepreneurship and Business Organization, 1720-1844. Cambridge, U.K., 2000.

Hoffmann, Walther G. Das Wachstum der deutschen Wirtschaft seit der Mitte des 19. Jahrhunderts. Berlin, 1965.

Jefferys, James B. Business Organisation in Great Britain, 1856-1914. New York, 1977.

Kuhn, Arthur K. A Comparative Study of the Law of Corporations with Particular Reference to the Protection of Creditors and Shareholders. New York, 1912.

Lyon-Caen, Charles, and Louis Renault. Manuel de droit commercial (y compris le droit maritime). Paris, 1924.

O’Neal, F. Hodge. Close Corporations: Law and Practice. 2 vols. Chicago, 1958.

Ripert, Georges. Traité élémentaire de droit commercial. 6th ed. Paris, 1967-1970.

Rosenberg, Nathan, and L. E. Birdzell, Jr. How the West Grew Rich: The Economic Transformation of the Industrial World. New York, 1986.

Roy, William G. Socializing Capital: The Rise of the Large Industrial Corporation in America. Princeton, N.J., 1997.

Schmidt, Karsten. Gesellschaftsrecht. $4^{\text {th }}$ ed. Berlin, 2002.

Stamp, J. C. British Incomes and Property: The Application of Official Statistics to Economic Problems. London, 1916.

Wagon Eduard. Die finanzielle Entwicklung deutscher Aktiengesellschaften von 1870-1900 und die Gesellschaften mit beschränkter Haftung im Jahre 1900. Halle, 1903.

Warren, Edward H. Corporate Advantages Without Incorporation. New York, 1929. 
Articles and Essays

Blair, Margaret M. "Locking in Capital: What Corporate Law Achieved for Business Organizers in the Nineteenth Century." UCLA Law Review 51 (Dec. 2003): 387-455.

Bolton, Patrick, and Ernst-Ludwig Von Thadden. "Blocks, Liquidity and Corporate Control.” Journal of Finance 53 (Feb. 1998): 1-25.

Cameron, Rondo. "The Founding of the Bank of Darmstadt." Explorations in Entrepreneurial History 8 (Feb. 1956): 112-30.

Cull, Robert, Lance E. Davis, Naomi R. Lamoreaux, and Jean-Laurent Rosenthal. "Historical Financing of Small- and Medium-Size Enterprises." Journal of Banking and Finance 30 (Nov. 2006): 3017-42.

Demsetz, Harold. "Wealth Distribution and Ownership Rights." Journal of Legal Studies 1 (June 1972): 223-32.

Demsetz, Harold, and Kenneth Lehn. "The Structure of Corporate Ownership: Causes and Consequences.” Journal of Political Economy 93 (Dec. 1985): 1155-77.

De Vries, Henry P., and Friedrich K. Jünger. "Limited Liability Contract: The GmbH,” Columbia Law Review 64 (May 1964): 866-86.

Dickinson, Kelvin H. "Partners in a Corporate Cloak: The Emergence and Legitimacy of the Incorporated Partnership." American University Law Review 33 (Spring 1984): 559-600.

Dunlavy, Colleen A. "From Citizens to Plutocrats: Nineteenth-century Shareholder Voting Rights and Theories of the Corporation." In Constructing Corporate America: History, Politics, Culture, eds. Kenneth Lipartito and David B. Sicilia, New York, 2004, pp. 66-93.

Fohlin, Caroline. "Regulation, Taxation, and the Development of the German Universal Banking System, 1884-1913.” European Review of Economic History 6 (Aug. 2002): 221-54.

Gazur, Wayne M., and Neil M. Goff. "Assessing the Limited Liability Company." Case Western Reserve Law Review 41 no. 2 (1991): 387-501.

Getzler, Joshua, and Mike Macnair. “The Firm as an Entity before the Companies Act." In Adventures in the Law: Proceedings of the 16th British Legal History Conference, eds. Paul Brand, Kevin Costello, and W. N. Osborough, Dublin, 2003, pp. 267-88.

Gower, L. C. B. "Some Contrasts Between British and American Corporation Law.” Harvard Law Review 69 (June 1956): 1369-1402.

Guinnane, Timothy W. "Delegated Monitors, Large and Small: Germany’s Banking System, 1800-1914." Journal of Economic Literature 40 (March 2002): 73-124.

Hansmann, Henry, and Reinier Kraakman. "The Essential Role of Organizational Law.” Yale Law Journal 110 (Dec. 2000): 387-440.

Hansmann Henry, and Richard Squire. "Law and the Rise of the Firm." Harvard Law Review 119 (March 2006): 1333-1403.

Horn, Nobert. "Aktienrechtliche Unternehmensorganisation in der Hocindustrialisierung (1860-1920)." In Recht und Entwicklung der 
Grossunternehmen im 19. und frühen 20. Jahrhundert, eds. Norbert Horn and Jürgen Kocka, Götting, 1979, pp. 123-89.

Hornstein, George D. "Stockholders' Agreements in the Closely Held Corporation." Yale Law Journal 59 (May 1950): 1040-56.

Howard, Stanley E. "The Limited Partnership in New Jersey." Journal of Business of the University of Chicago 7 (Oct. 1934): 296-317.

Hutcheon, Peter D. “The New Jersey Limited Liability Company Statute: Background and Concepts." Seton Hall Legislative Journal 18 no. 1 (1993): 111-60.

Keatinge, Robert R, et al. "The Limited Liability Company: A Study of the Emerging Entity.” Business Lawyer 47 no. 2 (1991-92): 375-460.

Kocka, Jürgen, and Hannes Siegrist. "Die hundert größten deutschen Industrieunternehmen im späten 19. und frühen 20. Jahrhundert." In Recht und Entwicklung der Grossunternehmen im 19. und frühen 20. Jahrhundert: Wirtschafts-, sozial- und rechtshistorische Untersuchungen zur Industrialisierung in Deutschland, Frankreich, England und den USA, eds. Norbert Horn and Jürgen Kocka, Göttingen, 1979, pp. 55-122.

Lamoreaux, Naomi R. "Constructing Firms: Partnerships and Alternative Contractual Arrangements in Early-Nineteenth-Century American Business." Business and Economic History 24 (Winter 1995): 43-71.

Lamoreaux, Naomi R., and Jean-Laurent Rosenthal. "Corporate Governance and the Plight of Minority Shareholders in the United States before the Great Depression." In Corruption and Reform: Lessons from America's Economic History, Edward L. Glaeser and Claudia Goldin, eds. Chicago, 2006, pp. 125-52.

"Legal Regime and Contractual Flexibility: A Comparison of Business's Organizational Choices in France and the United States during the Era of Industrialization." American Law and Economics Review 7 (Spring 2005): 28-61.

La Porta, Rafael, Florencio Lopez-de-Silanes, Andrei Shleifer, and Robert W. Vishny. "Law and Finance." Journal of Political Economy 106 (Dec. 1998): 1113-55.

. "Legal Determinants of External Finance." Journal of Finance 52 (July 1997): 1131-50.

. "The Quality of Government." Journal of Law, Economics, and Organization 15 (March 1999): 222-79.

Lewis, William Draper. "The Uniform Limited Partnership Act." University of Pennsylvania Law Review 65 (June 1917): 715-31.

L.I.M. "Notes: Business Associations in Pennsylvania." University of Pennsylvania Law Review 82 (Dec. 1933): 151-57.

Matthews, James A., Jr. "Comments: Business Associations-Registered Partnership, Partnership Association or the Corporation-Selection of the Suitable Form in Pennsylvania." Villanova Law Review 2 (April 1957): 385-95.

O’Neal, F. Hodge. "Close Corporations: Existing Legislation and Recommended Reform.” The Business Lawyer 33 (Jan. 1978): 873-88. 
. "Developments in the Regulation of the Close Corporation." Cornell Law Quarterly 50 (Summer 1965): 641-62.

. "Giving Shareholders Power to Veto Corporate Decisions: Use of Special Charter and By-Law Provisions." Law and Contemporary Problems 18 (Autumn 1953): 451-72.

Pagano, Marco, and Ailsa Roell. "The Choice of Stock Ownership Structure: Agency Costs, Monitoring, and the Decision to Go Public." Quarterly Journal of Economics 113 (Feb. 1998): 187-225.

Passow, Richard. "Der Anteil der verschiedenen privaten Unternehmungsformen und der öffentlichen Betrieben am deutschen Wirtschaftsleben." Jahrbücher für Nationalökonomie und Statistik N.F. 96 no. 4 (1911): 506-25.

Petska, Thomas B. "Taxes and Organizational Choice: An Analysis of Trends, 1985-1992." SOI Bulletin 15 (Spring 1996): 86-102.

Petska, Thomas B., and Robert A. Wilson. "Trends in Business Structure and Activity, 1980-1990." SOI Bulletin 13 (Spring 1994): 27-72.

Schubert, Werner. "Die Gesellschaft mit beschränkter Haftung. Eine neue juristische Person." Quaderni fiorentini per la storia del pensiero guiridico moderno 11/12 (1982): 589-629.

Schwartz, Edward R. "The Limited Partnership Association-An Alternative to the Corporation for the Small Business with 'Control' Problems?" Rutgers Law Review 20 (Fall 1965): 29-88.

Stover, Fallany O., and Susan Pace Hamill. "The LLC Versus LLP Conundrum: Advice for Businesses Contemplating the Choice." Alabama Law Review 50 (Spring 1999): 813-47.

Stransky, George E., Jr. “The Limited Partnership Association in New Jersey.” Rutgers Law Review 10 (Summer 1956): 701-15.

Tirole, Jean. “Corporate Governance.” Econometrica 69 (Jan. 2001): 1-35.

Woodward, Susan E. "Limited Liability in the Theory of the Firm." Journal of Institutional and Theoretical Economics 141 (Dec. 1985): 601-11.

Zweibel, Jeffrey. "Block Investment and Partial Benefits of Corporate Control.” Review of Economic Studies 62 (April 1995): 161-85.

Legal Documents

Appeal of Hite Natural Gas Co., 118 Pa. 4361888.

Benintendi v. Kenton Hotel, 294 NY 1121945.

Edwards v. Warren Linoline \& Gasoline Works, 168 Mass. 5641897.

Eliot v. Himrod, 108 Pa. 5691885.

Gearing v. Carroll, 151 Pa. 791892.

In the Matter of Boulevard Theatre and Realty Company, 186 N.Y.S. 1921.

Jackson v. Hooper, 76 N.J. Eq. 5921910.

Maloney v. Bruce, 94 Pa. 2491880.

Salomon v. Salomon, A.C. 221897.

Sheble v. Strong, 128 Pa. 3151889.

Vanhorn v. Corcoran, 127 Pa. 2551889. 
Government Documents and Reports

Annuaire Statistique de la Justice, formerly Compte général de l'administration de la justice civile, commerciale et criminelle. Paris, 1840-1978.

Code de commerce, suivi des lois commerciales et industrielles, avec annotations d'après la doctrine et la jurisprudence et renvois aux publications Dalloz. 63rd ed. Paris, 1967.

Compiled Statutes of New Jersey. Newark, 1911.

Deutscher Reichsanzeiger und preussischer Staatsanzeiger. Berlin, 1867-1932.

Documents Parlementaires. Paris, 1921-1925.

Gesetz, betreffend die Kommanditgesellschaften auf Aktien und die Aktiengesellschaften, vom 18. Juli 1884/Mit Erlauterung von Paul Kayser. Berlin, 1884.

Page William Herbert, ed. New Annotated Ohio General Code. Cincinnati, Ohio, 1926.

Statistisches Jahrbuch für den Preussischen Staat. Berlin, 1915, vol. 12.

Stewart, Ardemus, comp. A Digest of the Statute Law of the State of Pennsylvania from the Year 1700 to 1903. Philadelphia, 1905.

U.K. Board of Trade. General Annual Report. London, 1922-2000.

U.K. Board of Trade. General Annual Report under the Companies (Winding-up) Act of 1890. London, 1900-1921.

U.K. Companies Act 1900 (63 \& 64 Vict. c. 48).

U.K. Companies Act 1907 (7 Edw. 7 c. 50).

U.K. Companies (Consolidation) Act, 1908 (8 Edw. 7 Ch. 69).

U.K. Parliamentary Papers. London, 1890-1922.

U.S. Session Laws of American States and Territories. Westport, Conn., 1874-1895.

U.S. Census Office. Census of Manufactures. Washington, D.C., 19001920.

Archival and Unpublished Sources

Bebchuk, Lucian Arye. "Asymmetric Information and the Choice of Corporate Arrangements." Harvard Law School Discussion Paper no. 398. Dec. 2002.

Grandy, Christopher. "The Economics of Multiple Governments: New Jersey Corporate Chartermongering, 1875-1929." Ph.D. diss., University of California, Berkeley, 1987.

Lamoreaux, Naomi R., and Jean-Laurent Rosenthal. "Contractual Tradeoffs and SME's Choice of Organizational Form: A View from U.S. and French History." NBER Working Paper no. W12455. Aug. 2006.

Tribunal de Commerce. Greffe du Tribunal. Enregistrement des Sociétés. Serie D32U3, registers 110-113, 115-117, 169, Archives de Paris. 